\title{
The Basel Accord and Financial Intermediation: The Impact of Policy
}

\author{
Martin Berka and Christian Zimmermann
}

\begin{abstract}
This article studies loan activity in a context where banks have to follow Basel Accord-type rules and find financing with the households. Loan activity typically decreases when investment returns of entrepreneurs decline, and we study which type of policy could invigorate an economy in a trough. The authors find that an active monetary policy increases loan volume even when the economy is in good shape, while the introduction of an active capital requirement policy is also effective if it implies tightening of regulation in bad times. This is performed with a heterogeneous agent economy with occupational choice, financial intermediation, and aggregate shocks to the distribution of entrepreneurial returns. (JEL E44, E22, G28, E58)
\end{abstract}

Federal Reserve Bank of St. Louis Review, Second Quarter 2018, 100(2), pp. 171-200. https://doi.org/10.20955/r.2018.171-200

\section{INTRODUCTION}

How can a central bank influence the availability of credit through the business cycle? Banks limit the loans they offer because (1) the loans may not provide a sufficient return; (2) the loans are too risky; (3) interest margins are too low; (4) there are regulatory constraints; and (5) there is a lack of funds. The literature on financial intermediation traditionally has neglected the last two points, especially the lack of funds. With this article, we take better account of the funding of banks and how it interacts with the two policy tools available to the central bank: monetary policy through the adjustment of some interest rates and regulatory policy through the variation of capital requirements.

We find that monetary policy matters most in terms of expectations. Indeed, the fact that the central bank commits to act in certain, possibly rare, situations is more important than the action itself. Households have a saving pattern that is more favorable to aggregate credit

Martin Berka is director of the Centre for Macroeconomics and a professor at the School of Economics and Finance at Massey University. Christian Zimmermann is assistant vice president of Research Information Services and an economist at the Federal Reserve Bank of St. Louis. This work was initiated while both authors were visiting the Bank of Canada. It benefited from much initial stimulus from Mingwei Yuan; from discussions with Scott Hendry, Césaire Meh, Kevin Moran, and Vincenzo Quadrini; and from seminar participants at the Universities of Alabama, Connecticut, and Montreal, Florida International University, Boston College, the Federal Reserve Bank of Dallas, the NBER Summer Institute, and the Midwest Macro Meetings at the Federal Reserve Bank of Chicago.

(c) 2018, Federal Reserve Bank of St. Louis. The views expressed in this article are those of the author(s) and do not necessarily reflect the views of the Bank of Canada, the Federal Reserve System, the Board of Governors, or the regional Federal Reserve Banks. Articles may be reprinted, reproduced, published, distributed, displayed, and transmitted in their entirety if copyright notice, author name(s), and full citation are included. Abstracts, synopses, and other derivative works may be made only with prior written permission of the Federal Reserve Bank of St. Louis. 
creation in all periods if they know that banks will still be able to lend in recessions. The key here is that the central bank is predictable.

In addition, we find that adjusting capital requirements through a business cycle can be a powerful tool, but not in the usual way: In a recession, capital requirements should tighten. Again, expectations matter, and knowing that equity returns are assured even in recessions can make households more willing to put equity into banks in all periods of the business cycle. This additional funding compared with a policy of constant capital requirements more than offsets the loan reduction during the actual requirement tightening.

We obtain these results through simulations of a model economy with heterogeneous households facing unemployment, retirement, and death risks. They save for precautionary reasons and for retirement. In addition, their assets may be used to qualify for loans from the banking sector, in which case they manage as entrepreneurs a risky project that may lead to bankruptcy. Household savings are invested in bank deposits and bank equity. Banks provide loans to households and buy government bonds. As mentioned, the central bank sets capital requirements and the policy interest rate, in this case the return on government bonds.

When banks need to reduce their loan portfolio, the displaced entrepreneurs also become new equity holders, thereby acting as "automatic stabilizers." However, banks typically cut loans as a consequence of their loan portfolio becoming too risky, and households may then want to hold less equity in banks that are more risky. Whether banks have to tighten credit a good deal or not depends strongly on the distribution of assets across households and on household equity decisions. The policy tools of the central bank then become crucial in reassuring households in bad times and in encouraging them to invest in bank equity at all times.

One would first think that loosening those requirements in a trough would expand the loan mass. It appears that, on the contrary, tighter capital requirements increase the demand for bank equity and thus facilitate the financing of banks sufficiently to offset the reduction of allowable loans for a given amount of equity. Again, this highlights the importance of household saving decisions for the supply of bank capital. This result is particularly important in light of Basel Accords II and III and their more flexible regulations, which essentially tighten the equity requirements when the economy passes through a rough patch, as highlighted, for example, by Catarineu-Rabell, Jackson, and Tsomocos (2005).

Cyclicality of capital requirements was previously thought to have a negative impact on credit. For example, Kashyap and Stein (2004) argue that Basel Accord II exacerbates business cycle fluctuations by requiring banks to hold more capital during downturns. Higher costs of raising capital in downturns force banks to further contract lending, which causes a credit crunch. However, such a demand-side argument ignores the negative impact of declining capital adequacy on the supply of bank capital. Rising funding costs in bad times are partly a result of a drop in the supply of banks' capital because of banks' deteriorating capitalization. Our model articulates both of the channels. Under standard calibration, the supply-side channel in our model dominates the demand considerations highlighted in Kashyap and Stein (2004). Consequently, more stringent capital adequacy requirements help bank recapitalization and facilitate a smoother loan time-path. The conservative lending behavior implied by such a policy in the face of increased aggregate uncertainty has been observed in the data, for example, by Baum, Caglayan, and Ozkan (2002). 
We are not the first to highlight the real impact of monetary policy through lending. Bernanke and Gertler (1995) highlight two channels. In the balance sheet channel, Federal Reserve System policy affects the financial position of borrowers and hence their ability to post collateral or to self-finance. In the bank lending channel, Fed policy shifts the supply of bank credit, particularly loans. $\underline{1}$ They argue that the importance of the latter channel has declined with deregulation, as this channel relies on reserves. Our model does not rely on reserves. Van den Heuvel (2002) identifies another channel stemming specifically from Basel Accord-type rules. The "bank capital channel" arises from maturity transformation through banks: Higher short-term interest rates depress profits and, consequently, equity and capital adequacy. All of this is in an environment with an imperfect market for bank equity, which forces banks to raise new equity by retaining their earnings. His model has a very detailed banking structure, but it neglects the problems of households and firms. Our model has a simpler banking structure that does not rely on imperfection in the equity market but does emphasize the source of financing (households) and the demand for loans (entrepreneurs) by modeling occupational choice, savings, and bankruptcy. $\underline{2}$

Chami and Cosimano (2010) identify a "bank balance sheet channel," using the concept of increasing the marginal cost of external financing. Oligopolistic banks avoid expected profit declines caused by the anticipation of a binding capital adequacy constraint by holding capital above the regulatory level. Tighter monetary policy raises banks' cost of funding and reduces loan supply. A persistent increase in deposit rates reduces the option value of bank capital, further propagating the loan contraction. As Van den Heuvel (2002) reports, Chami and Cosimano's model needs market power in the banking industry to obtain the result. Our model has fully competitive banks. Furthermore, Chami and Cosimano summarize the demand for loans with a reduced form, while we try to present a general equilibrium framework. Bolton and Freixas (2006) have a model in which higher costliness of bank capital, due to asymmetric information about the quality of banks' assets, motivates banks to hold the minimum required amount of capital. Capital requirements are a cause of the credit crunch when spreads are low. Monetary policy tightening operates by pricing riskier firms out of the loan market. Our model puts more emphasis on the financing side and does not impose the asymmetric information assumption. In a model where banks and entrepreneurs face moral hazard, Meh and Moran (2004) show that responses to monetary and technology shocks are dampened but more persistent. The bank capital/asset ratio in their model is countercyclical like in the data, but the authors do not explore the behavior of credit. $\underline{3}$ The discussion of cyclicality of capital requirements has intensified recently. Covas and Fujita (2010) extend Kato's (2006) model of liquidity provision under asymmetric information with bank capital requirements. They find that Basel II-type cyclical capital requirements reduce household welfare by increasing output volatility. In an overlapping generations framework from Repullo and Suarez (2013), banks cannot access equity markets each period and consequently hold large capital buffers. Buffers are insufficient to prevent credit contractions in downturns. In a static partial equilibrium model, Heid (2007) shows that capital buffers held by banks, in addition to the Basel II requirements, strongly influence the degree of cyclical magnification of the business cycle.

The major point of difference in our model is the heterogeneity of agents who make saving decisions. Loan applicants are endogenously divided into entrepreneurs and depositors 
according to their wealth. Not only is the loan supply and demand endogenous, changes in macroeconomic conditions generate distributional effects that feed back to the aggregate level in a general equilibrium setting. Because of these distributional considerations, Basel II-type requirements do not magnify the downturns, unlike in all the work discussed above. In fact, ours is the first model in which tightening of the capital adequacy requirements in bad times facilitates bank funding - by lowering the risk of bank equity and making it more attractive to savers. Such effects cannot be found in the literature, as it neglects bank funding. Credit constraints in our model lead to asymmetric effects of the monetary policy, with tightening having more significant real consequences than monetary policy loosening (one of the key properties of a monetary propagation mechanism in general, as highlighted by Kocherlakota, 2000). Furthermore, our model is the only one so far that can be used for addressing both the aggregate effects and the redistribution effects of credit market policies.

The structure of this article is as follows. Section 2 presents the model. Section 3 presents the calibration of the model. Section 4 analyzes bank lending and optimal monetary policy behavior following negative shocks. Section 5 concludes. Appendices give additional details about various aspects of the model and the solution strategy.

\section{MODEL}

\subsection{Overview}

There are three types of agents in the economy: households, banks, and a central bank. Households in a productive stage of their lives aim to become entrepreneurs, but a shortage of internal financing forces them to apply for external funds. Successful applicants become entrepreneurs while others remain workers. Each worker faces an idiosyncratic shock of becoming unemployed, while the entrepreneurs face risky returns on their investments. ${ }^{4}$ All households in a productive stage of life (entrepreneurs, employed workers, and unemployed workers) face a risk of becoming permanently retired, and all retirees face a risk of dying. New households are born to replace the deceased ones.

When households make their consumption-saving decisions, they decide optimally on allocation of their savings between insured bank deposits and risky bank equity. Risk-neutral banks collect deposits and equity, provide loans to entrepreneurs, and purchase risk-free government bonds to maximize their profits. Banks screen loan applications and accept them according to the level of each household's net worth. Banks also have to purchase deposit insurance and are subject to a capital adequacy requirement imposed by the central bank. The central bank controls the government bond rate.

If entrepreneurship is an attractive option, households in this model economy strive to accumulate assets in order to qualify for bank loans. The banks, though, are restricted by potential losses from bad loans and by capital requirements. They react to changes in economic conditions, the policy interest rate, and capital requirements by adjusting the loan supply and loan interest rate. This in turn has bearing on the eagerness of households to save and supply funds to the banks in the form of deposits and bank equity. 
We now go through the model in more detail. The economy is subject to aggregate shocks and can thus be represented by an aggregate state vector, including the current shock to the distribution of returns and the current distribution of assets and occupations that we ignore in the following to simplify notation.

\subsection{Households}

In the model economy, there is a continuum of measure one of households, each maximizing their expected discounted lifetime utility by choosing an optimal consumption-saving path. A household can be either productive or retired, and the probability of a productive household retiring $\tau$ is exogenous. $\underline{5}$

Each productive household is endowed with one investment project of size $x$, which is always greater than the household's net worth $m$, a state variable determined in the previous period. This imposes a credit constraint on the household. For simplicity we assume that the project is a fixed multiple of a household's last period's net worth: $x=\phi m$, where $\phi>1$. The project is indivisible, so $(\phi-1) m$ has to be funded by the bank for a project to be undertaken. ${ }^{6}$ If a household receives a bank loan, it becomes an entrepreneur and invests in a risky project. We study an equilibrium in which this participation constraint is satisfied for entrepreneurship: When eligible for a loan, households always choose to take it. The returns on investment are not certain. This risk constitutes an aggregate source of variation in our model that may lead to a positive probability of bankruptcy, in which case a household is guaranteed a minimal amount of consumption $c_{\min }$ and starts next period with no assets. ${ }^{-}$

If the bank rejects a loan application, the household enters the workforce and faces exogenous probabilities $1-u$ of becoming employed and $u$ of becoming unemployed. Workers receive an exogenous after-tax labor income $y$. Unemployed workers receive unemployment benefits $\theta y$, where $\theta<1$. After retirement, which happens with probability $\tau$, the household earns income from its savings and an exogenous pension, which equals the unemployment benefit payments. Retirees face a probability $\delta$ of dying. They are then replaced by agents with no assets, and any remaining assets are lost (no bequests).

Labor income is an exogenous endowment in our model. Specifically, the hourly wage $w$, which then determines labor income in each group of agents, is constant. This allows our model to focus on the roles played by the heterogeneous asset-allocation decisions within each agent group, the movement of agents between the groups, and the propagation in the banking sector. $\underline{-}$ We use aggregate data on average hours per worker to calibrate the constant wage received by workers, and we use other aggregate data sources to calibrate the labor income of other groups of agents relative to workers.

The households make their consumption-saving decisions to maximize their expected lifetime utility. The contemporaneous utility function is a CRRA type:

$$
U\left(c, l_{i}\right)=\frac{\left(l_{i}^{\sigma} c^{1-\sigma}\right)^{1-\rho}-1}{1-\rho},
$$

where, $i \in\{W, U, E, R\}, l$ denotes leisure, $c$ is consumption, and $\rho$ is a risk-aversion parameter. 
Let $V_{j}$ denote the value functions and $m^{*}$ be the minimum net worth necessary for external financing. A worker with a net worth $m<m^{*}$ faces probability $(1-u)$ of being employed, following which the worker receives labor income $y=\left(1-l_{W}\right) w$ and saving income $r_{i}^{\text {port }} m$, pays a banking fee $\xi,-$ consumes a desired level, and invests his or her remaining net worth $m^{\prime}$ in a bank. 10 If unemployed, a worker receives unemployment benefit payment $\theta y$ and makes a similar consumption-saving decision. In the next period, depending on the level of $m^{\prime}$, a worker may either become an entrepreneur (borrower) or remain a worker (depositor).

For an employed worker, the Bellman equation is

$$
\begin{aligned}
V_{W}(m) & =\max _{c, m^{\prime}}\left\{U_{W}\left(l_{W}, c\right)+\beta\left[( 1 - \tau ) \left[(1-u) 1_{m^{\prime}<m^{*}} V_{W}\left(m^{\prime}\right)+\right.\right.\right. \\
& \left.\left.\left.u 1_{m^{\prime}<m^{*}} V_{U}\left(m^{\prime}\right)+1_{m^{\prime} \geq m^{*}} E_{r^{\prime}} V_{E}\left(m^{\prime}, r^{i^{\prime}}\right)\right]+\tau V_{R}\left(m^{\prime}\right)\right]\right\}
\end{aligned}
$$

subject to

$$
c+m^{\prime}=\left(1+r_{E}^{\text {port }}\right) m+y-\xi, m, m^{\prime} \geq 0 .
$$

For an unemployed worker:

$$
\begin{aligned}
V_{U}(m) & =\max _{c, m^{\prime}}\left\{U_{U}\left(l_{U}, c\right)+\beta\left[( 1 - \tau ) \left[(1-u) 1_{m^{\prime}<m^{*}} V_{W}\left(m^{\prime}\right)+\right.\right.\right. \\
& \left.\left.\left.u 1_{m^{\prime}<m^{*}} V_{U}\left(m^{\prime}\right)+1_{m^{\prime} \geq m^{*}} E_{r^{\prime}} V_{E}\left(m^{\prime}, r^{i^{\prime}}\right)\right]+\tau V_{R}\left(m^{\prime}\right)\right]\right\}
\end{aligned}
$$

subject to

$$
c+m^{\prime}=\left(1+r_{U}^{\text {port }}\right) m+\theta y-\xi, m, m^{\prime} \geq 0
$$

An entrepreneur $i$ invests in a project of size $x^{i}$, earns a stochastic net return $r^{i}$ and labor income $y=\left(1-l_{E}\right) w$, and pays the borrowing $\operatorname{cost} r^{l}\left(x^{i}-m^{i}\right)$ while making a consumptionsaving decision to maximize his or her expected utility. The returns are stochastic in a way that changes with the aggregate state of the economy. Because the net wealth is constrained to be non-negative, significant project losses may drive the entrepreneur into bankruptcy. When bankrupt, an entrepreneur defaults on the portion of the debt he or she cannot repay less a minimal consumption allowance $c_{\text {min }}$, which has to be granted by the bank. Upon default, the entrepreneur starts the next period as a household with no assets and no liabilities. The value function of an entrepreneur is as follows:

$$
\begin{aligned}
V_{E}\left(m, r^{i}\right)= & \max _{c, m^{\prime}}\left\{U_{E}\left(l_{E}, c\right)+\beta\left[( 1 - \tau ) \left[(1-u) 1_{m^{\prime}<m^{* \prime}} V_{W}\left(m^{\prime}\right)+\right.\right.\right. \\
& \left.\left.\left.u 1_{m^{\prime}<m^{*}} V_{U}\left(m^{\prime}\right)+1_{m^{\prime} \geq m^{*}} E_{r^{\prime}} V_{E}\left(m^{\prime}, r^{i^{\prime}}\right)\right]+\tau V_{R}\left(m^{\prime}\right)\right]\right\}
\end{aligned}
$$

subject to

$$
\begin{gathered}
c=\max \left\{c_{\text {min }}, m+y+\left(1+r^{i}\right) x-r^{l}(x-m)-\xi-m^{\prime}\right\} \\
x=\phi m, m, m^{\prime} \geq 0 .
\end{gathered}
$$


We assume that households ex ante always prefer to apply for a loan. This implies a participation constraint for households in a productive stage of their lives that needs to be satisfied for all households that obtain a loan:

$$
E_{r} V_{E}(m, r) \geq(1-u) V_{W}(m)+u V_{U}(m), \quad \forall m \geq m^{*}
$$

Every household faces an exogenous probability of retirement $\tau$. Once retired, the household collects retirement income $y_{R}=\theta w$ and manages its assets subject to the risk of death $\delta$ :

$$
V_{R}(m)=\max _{c^{i}, m_{i}^{i}}\left\{U_{R}(1, c)+\beta\left[(1-\delta) V_{R}\left(m^{\prime}\right)\right]\right\}
$$

subject to

$$
c+m^{\prime}=\left(1+r_{R}^{\text {port }}\right) m+y_{R}-\xi
$$

Risk-averse agents smooth their consumption over time. Heterogeneous risks of unemployment and retirement, as well as the heterogeneity in project returns, cause uncertain income streams and lead to a non-degenerate distribution of assets in the economy. These risks are necessary to generate saving motives in an economy with a constant labor income. Without them there would be no reason to save other than to invest in a project, and the asset distribution would unrealistically collapse along $m=0$. This would make financial intermediation impossible due to the lack of funds (no depositors). $\underline{11}$ Furthermore, as pointed out by Chatterjee et al. (2007), there would be no bankruptcy without agent heterogeneity.

The decision to allocate savings between bank equity and bank deposits is obtained by maximizing a risk-adjusted return on portfolio $r_{i}^{\text {port }}$ across agent types $i, i \in\{W, U, R\}$. While we allow for different groups of agents to have a different composition of risky and safe assets within a portfolio, for computation reasons we do not allow for a within-group heterogeneity. $\underline{12}$ The problem is

$$
\max _{\omega_{r i}} r_{i}^{\text {port }}-\frac{1}{2} \lambda_{i} \sigma_{\text {port }}^{2}
$$

where $r_{i}^{\text {port }}=r^{e} \frac{E_{i}}{M_{i}}+r^{d} \frac{D_{i}}{M_{i}}=\omega_{r i} r^{e}+\left(1-\omega_{r i}\right) r^{d}, \omega_{r i} \equiv E_{i} / M_{i}$ is a weight on the risky (equity) investment for agent type $i, \lambda_{i}$ is a risk-aversion parameter that varies across agent groups, and $\sigma_{\text {port }}^{2}$ is a variance of the portfolio return. Because bank deposits carry no risk $\left(\sigma_{d}^{2}=0\right)$, the household maximizes:

$$
\max _{\omega_{r i}} \omega_{r i} r^{e}+\left(1-\omega_{r i}\right) r^{d}-\frac{1}{2} \lambda_{i} \omega_{r i}^{2} \sigma_{e}^{2},
$$

which yields the optimal share of equity $\omega_{r i}^{*}=\frac{r^{e}-r^{d}}{\lambda_{i} \sigma_{e}^{2}}$. This in turn defines the demand for equity (and implicitly for deposits) given savings $M_{i}$ for any agent group: 


$$
\frac{E_{i}}{M_{i}}=\frac{r^{e}-r^{d}}{\lambda_{i} \sigma_{e}^{2}} .
$$

Note that we have separated this portfolio problem from the intertemporal utility maximization of the household. We do this for computational reasons: Given that with aggregate shocks we need to include the entire asset distribution in the state space, we need to avoid having to track two separate assets for each household to keep the state space dimensionality within computationally efficient bounds. Appendix B shows that some details of making saving decisions depend on asset levels.

\subsection{Financial Sector}

The representative bank maximizes its expected profits, taking the asset distribution in the economy as given. Profits equal asset returns less the funding costs, the deposit insurance payments, and the expected loan losses and liquidation costs. The bank's choice variables are loans $L$, bonds $B$, equity $E$, and deposits $D$. Because the bank takes the distribution of assets and all returns as given, choosing how much to loan out is identical to choosing the threshold level of net worth $m^{*}$ required for an entrepreneur to get a loan. Formally, the problem can be stated as

$$
\max _{L, B, D, E} r^{l} L+r^{b} B-r^{d} D-r^{e} E-\kappa\left(\frac{D}{E}\right)^{\gamma} D-(1+l c) \varepsilon L+\xi
$$

subject to

$$
\begin{gathered}
B+L=D+E \equiv M \\
\left(\frac{E}{L}\right) \geq \alpha \\
D+E \geq L,
\end{gathered}
$$

where $M$ is the total amount of loanable funds that are exogenous from the point of view of the bank; deposit insurance cost parameter $\varepsilon$ is an expected share of loan losses that are endogenous to the equilibrium outcomes in a particular state of the economy; $l c$ is a cost parameter that reflects losses during bankruptcy, liquidation proceedings, and auditing costs; and $\xi$ is a bank fee paid by the households. Equation (8) is the usual balance sheet constraint, (9) is the regulatory requirement on capital adequacy, and (10) is a non-negativity constraint on bond holdings. The profit function (7) is nonlinear because of the imposition of deposit insurance costs, which are an increasing function of the deposit/equity ratio. For any given asset distribution, banks will make more profits if the loan mass is larger. This implies that only one of the constraints (9) and (10) will bind at any time except in very rare circumstances where both bind. Banks' profits are zero on average. The solution of the profit maximization is described in Appendix A. 


\subsection{Central Bank}

The central bank in this model determines the bond interest rate $r^{b}$ and supplies government bonds at that rate. In addition, it determines the capital-to-asset ratio parameter $\alpha$. Therefore, $\alpha$ and $r^{b}$ are the only monetary policy instruments the bank has at its disposal. In the simulation in Section 4, we show how different monetary policy actions, as represented by mean-preserving changes in $r^{b}$ across the aggregate states, influence the behavior of the different types of households and of the representative bank. We also do similar exercises with mean-preserving changes in the capital requirements.

\subsection{Market Clearing}

On the financial side, markets for loans, bonds, equity, and deposits must clear in all states. The bond market clears automatically because of an infinitely elastic supply of bonds. $\frac{13}{3}$ The savings by non-entrepreneur households are allocated into deposits (share $1-\omega_{r}$ and share $\omega_{r}$ ) and equal offerings by banks (equations 11 and 12). Loans supplied by the bank system equal the mass of all projects less the entrepreneurs' assets (equation 13). The banks' balance sheets are defined in equation (14):

$$
\begin{gathered}
D^{S}=D^{D}=\left(1-\Omega_{r}\right) \sum_{m<m^{*}} m \mu(m) \\
E^{S}=E^{D}=\Omega_{r} \sum_{m<m^{*}} m \mu(m) \\
L=\sum_{m \geq m^{*}}(\phi-1) m \mu(m) \\
M=\sum_{m<m^{*}} m^{i} \mu(m)=D+E=B+L,
\end{gathered}
$$

where

$$
\Omega_{r}=(1-u) \frac{\delta}{\tau+\delta} \omega_{r W}+u \frac{\delta}{\tau+\delta} \omega_{r U}+\frac{\tau}{\tau+\delta} \omega_{r R}
$$

Also, expected losses of the bank must in equilibrium equal the realized loan losses:

$$
\varepsilon=\sum_{m \geq m^{*}} \max \left\{0,(1+a)\left[r^{l}(\phi-1) m-\phi m(1+r)\right]+c_{m i n}\right\} \mu(m),
$$

where $a$ is auditing and liquidation costs.

Equity market clearing implicitly defines the return on equity $r^{e}$ as a function of all other returns. See Appendix A for mathematical developments.

To illustrate the functioning of the equity market, it is useful to undergo the following thought experiment. Consider a case of an increase in the lending interest rate $r^{l}$, which may be due to a higher demand for loans as a result of a better aggregate state. If the ratio of expected losses as a proportion of loans $\varepsilon$ rises less than $r^{l}$, then the profit margin grows, which prompts the bank to lend more. Starting from a binding capital adequacy constraint, the bank needs 
to raise more equity. But with the household's demand for equity (6) unchanged, the bank must offer a higher return $r^{e}$ to raise more equity. Such a rise in $r^{e}$ facilitates an increase in equity while simultaneously easing the $E / D$ constraint for any given $M . \underline{14}$ Thus, this increase in the share of loans in the bank's portfolio comes at an ever-increasing price of costlier equity. Eventually, the incipient profit margin disappears and a new optimal loan level is achieved. $\underline{15}$

\subsection{Equilibrium}

A recursive equilibrium in this model economy comprises the four value functions $V_{j}(m, s)$, where $s$ represents the aggregate state (current shock to the distribution of project returns, distribution of $m)$ for $j \in\{E, W, U, R\}$, decision rules $\left\{g_{j}^{m}(m, s), g_{M}^{d}(s), g_{M}^{e}(s), g_{B}^{m^{*}}(s), g_{B}^{r^{l}}(s)\right\}$, government policies $\left\{\alpha(s), r^{b}(s)\right\}$, prices $\left\{r^{d}(s), r^{l}(s), r^{\text {port }}(s), r^{e}(s)\right\}$, aggregate asset levels $\{L, D, B, E\}$, and a function $\Psi(\mu)$ such that, subject to aggregate shocks to the distribution of project returns $\{r\}$ :

1. Decision rules $g_{j}^{m}(m, s)$ solve each household's problem with the associated value functions $V_{j}(m, s)$.

2. Decision rules $g_{M}^{d}(s)$ and $g_{M}^{e}(s)$ solve the portfolio problem of the household.

3. Decision rules $g_{B}^{m^{*}}(s)$ and $g_{B}^{r^{l}}(s)$ solve the banks' problems.

4. Loan, equity, and deposit markets clear:

$$
\begin{gathered}
L(s)=\sum_{m \geq m^{*}}(\phi-1) m \mu(m, s) \\
E(s)=\frac{r^{e}-r^{d}}{\lambda \sigma_{e}^{2}} \sum_{m<m^{*}} m \mu(m, s) \\
D(s)=\left(1-\frac{r^{e}-r^{d}}{\lambda \sigma_{e}^{2}}\right) \sum_{m<m^{*}} m \mu(m, s) .
\end{gathered}
$$

5. The distribution of households is the fixed point of the law of motion $\Psi$,

$$
\mu^{\prime}=\Psi(\mu)
$$

Note that there is no government budget constraint. The costs of unemployment benefits and retirement pensions vary very little across experiments, thus making endogenous tax rates largely irrelevant to the decisions of the agents. We therefore simplify the computational problem by abstracting from this.

\section{PARAMETERIZATION}

To simulate the economy and obtain numerical results, we parameterize the model to the Canadian economy for 1988-92, in accordance with the available data on project return distributions. Indeed, these are the only years for which Statistics Canada published such data.

First we calibrate the household sector. Several parameters are set in accordance with the literature: $\rho=2.5, \beta=0.96$, and $\sigma=0.67$. In agreement with the models that include explicit 
leisure specification, $l_{E}=l_{W}=l_{U}=0.55$ while $l_{R}=1$, as a result of which the labor input of entrepreneurs and workers and the search effort of the unemployed are set to 0.45 . Wages are exogenous, and while they completely characterize the labor income of entrepreneurs and workers, the incomes of the unemployed and retired are determined by the ratio of unemployment insurance benefits to wages $\theta=0.3 . \underline{16}$

The probability of unemployment is set equal to the average Canadian unemployment rate for the considered period, $u=0.0924$. The probability of retirement $\tau$ and the mortality rate $\delta$ are set at 0.05 and 0.1 , so the number of expected periods while a worker and a retiree are 20 and 10, respectively. A longer expected lifetime horizon generates a stronger wealth effect and, consequently, stronger responses of saving over time than in the usual two-period models (e.g., Williamson, 1987, and Bernanke and Gertler, 1989).

Now we turn to the financial side. Following the calibration in Yuan and Zimmermann (2004), which uses data from Canada, we can obtain all the necessary elements for our model. We set the real bond rate $r^{b}$ at 1 percent, such that the deposit rate $r^{d}$ is about 0.9 percent, which corresponds to an average of saving rates and guaranteed investment certificate rates. The parameter $\alpha$ of the capital adequacy constraint is taken to represent the tier-1 capital requirements imposed by the 1998 Basel Accord and set to $\alpha=0.08$. The deposit insurance parameter $\kappa$ is calibrated using the premium rates of the Canadian Deposit Insurance Corporation for banks in 2000 and 2001 (0.0417 percent of insured deposits). This per-unit rate corresponds to $\kappa=0.0000417$ for an average deposit/equity ratio of 10 . The loan administration $\operatorname{cost} l_{c}$ is assumed to equal zero. The account flat fee $\xi$ is set at 0.0003 by trial and error in order to get the banks to break even. The parameters of the equity market that need to be calibrated are $\lambda$ and $\sigma_{E}^{2}$. The variance of banks' returns on equity is calculated from the Toronto Stock Exchange monthly series on financial enterprises' returns on equity for September 1978 to December 2000, which are deflated by the consumer price index. Therefore, $\sigma_{E}^{2}=0.24$. The risk-aversion parameter of the portfolio optimization problem $\lambda$ is calibrated from the market clearing condition (22) using the observed average real deposit, lending, and return-on-equity rates. This implies $\lambda=16$.

The time-varying distribution of project returns is the exogenous source of aggregate shocks in our model. This distribution follows a two-state Markov process calibrated so that the high state occurs 75 percent of the time. Specifically, a high state has a 75 percent chance of reoccurring the next period, while a low state can repeat itself with a 25 percent chance. The distributions of project returns in both aggregate states are calibrated from firms' returnon-equity data. Statistics Canada (1994) reports the distribution of returns on equity by nonfinancial enterprises for the fourth quarter of 1988 to the fourth quarter of 1992. Average returns in each quarter are reported for the top, middle, and bottom tertiles. Assuming the underlying distribution is normal, we find the returns and associated probabilities for trinomial distributions such that (i) average returns are replicated, and (ii) we have two extreme returns, one implying bankruptcy. We compute two such distributions: one for the high aggregate state, corresponding to the average of the 75 percent best quarters in the sample period, and the other for the low state. The returns and associated distributions are the following: 


$$
\text { High: }\left(\begin{array}{rrr}
-50 \% & 5.2 \% & 60 \% \\
0.71 \% & 98.48 \% & 0.81 \%
\end{array}\right) \text { Low: }\left(\begin{array}{rrr}
-50 \% & 2.57 \% & 60 \% \\
1.79 \% & 97.42 \% & 0.79 \%
\end{array}\right) \text {. }
$$

The ratio of investment to net worth $(\phi-1)$ is calibrated to equal the average debt/equity ratio during the reference period, so $\phi=2.2$. With a minimum return on investment of -50 percent, we have occasional bankruptcies.

\section{CAPITAL REQUIREMENTS, BANK LENDING, AND MONETARY POLICY}

In this section, we want to understand the behavior of the model economy. This is no easy task, as the model is quite complex. The rich aggregate state space implies that many different histories of shocks can be studied. We focus here on one particular history that we believe is empirically relevant from the business cycle perspective. The model economy has been hit by a long sequence of high aggregate shocks; thus, the distribution of assets has converged to a high steady state. Given the way the shock process has been calibrated, the economy spends, on average, 50 percent of the time in the initial state of this experiment, a state that we will sometimes refer to as "normal times." Our experiment starts with a succession of five low shocks and then five high shocks. Thus, the model economy wanders through a whole cycle, bottoming out in the middle. Note that this is a particular history of shocks among many others and that this history is not anticipated.

Figure 1 shows the behavior of various indicators in a benchmark economy-that is, one with no policy intervention from the central bank on the interest rate for bonds or on capital requirements. When the initial bad shock hits the economy, the lending rate jumps up, essentially to protect against higher expected loan losses and because agents need time to adjust their asset holdings. As the negative shocks accumulate, the lending rate decreases as $m^{*}$ increases and households adjust their asset levels. Banks ration more and more loans as bad shocks accumulate but revert to "normal" behavior as soon as good news comes in. From peak to trough, the amount of loans decreases by 3.0 percent, and 3.6 percent of all entrepreneurs are driven out. The consequence is that the size of an average loan increases by 0.6 percent, which corresponds to the empirically documented phenomenon that small businesses suffer more in a downturn.

Do the results of the benchmark calibration imply a credit crunch? Despite the fact that banks can increase the interest rate on loans to compensate for higher default rates, they have to decrease the total loan mass. The reason is the following: Facing increased risk, more entrepreneurs are forced to become workers because of a higher bankruptcy rate. With more agents that save, the volume of assets increases. However, a smaller share of those assets is channeled to bank equity because its return is too low given its risk. The banks are then squeezed by capital requirements and have to ration credit and invest more into less profitable government bonds. Without capital requirements, banks could make more loans, in principle, by charging even higher loan rates, and entrepreneurs would still be ready to pay these rates. Although all agents behave optimally, we have a situation that can be described as a credit crunch to the extent that the marginal returns and the marginal costs of loans are not equal. 
Figure 1

\section{Benchmark Economy as It Cycles Through All Possible Aggregate States}
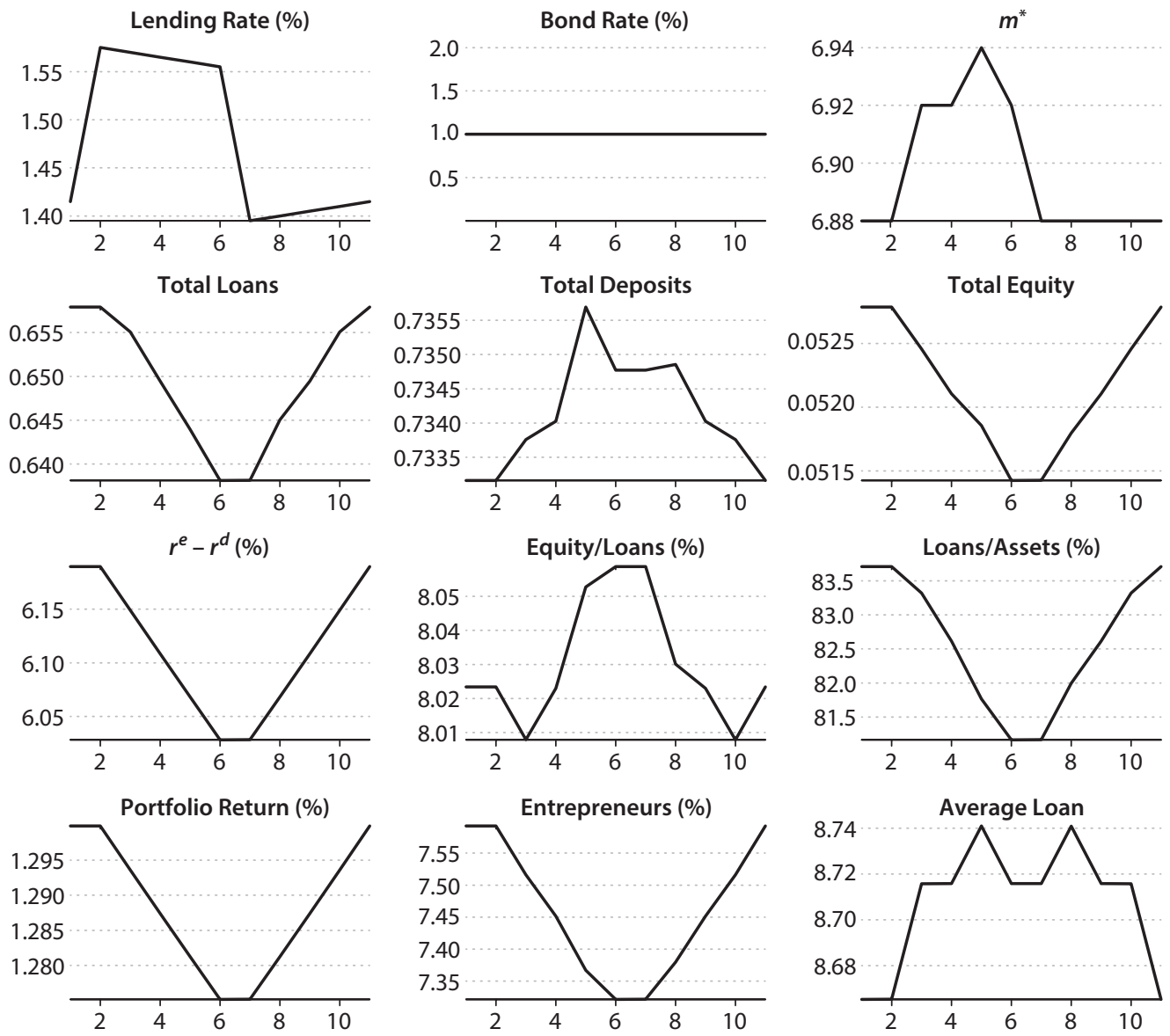

Capital requirements imply that changes in the composition of banks' liabilities affect the amount of credit in the economy. An adverse productivity shock increases the number of depositors and lowers the number of borrowers. Yet risk-averse depositors shy away from the risky bank equity, which leads to a further credit decline (because of the binding capital requirements). Thus, our unique heterogeneous agent setup generates "procyclical" bank capital requirements even without $\alpha$ dependent on risk. $\frac{17}{}$ However, the movements described above are relatively small.

\subsection{Countercyclical Monetary Policy}

By monetary policy, we mean a policy that changes an interest rate depending on the aggregate state of the economy. In our model, the policy rate is the government bond rate.

The following experiments explain the consequences of various policy actions. The first policy experiment, described in Figure 2, involves a 25-basis-point reduction of the bond rate in the worst aggregate state (current shock is low; long history of low shocks). $\underline{18}$ Thus, the 
Figure 2

Benchmark and Policy with Interest Rate Reduction in Worst Case Only
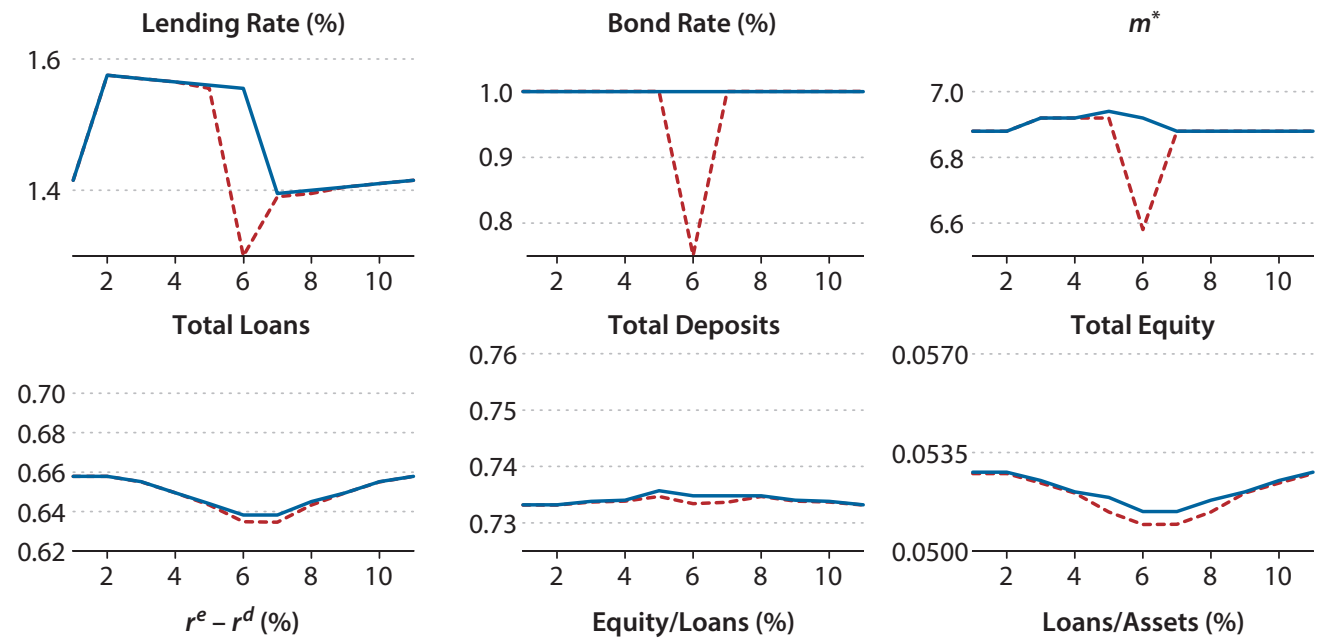

0.0570
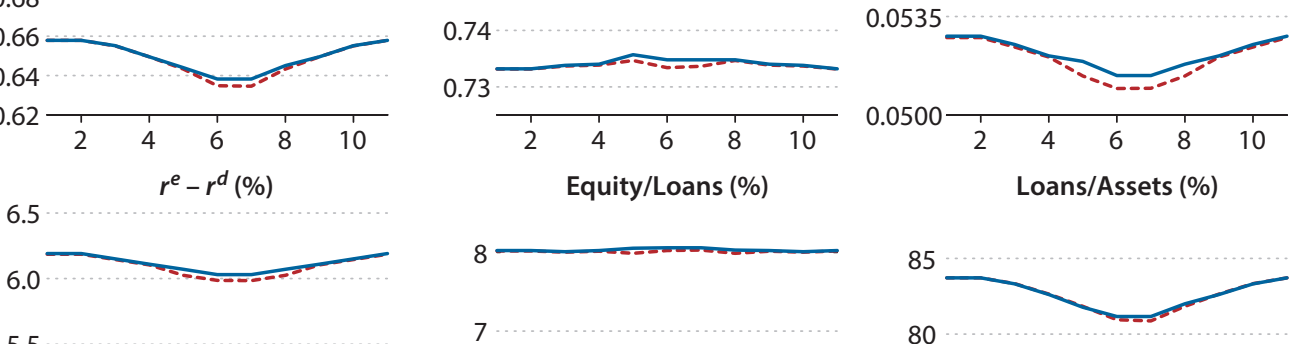

5.5
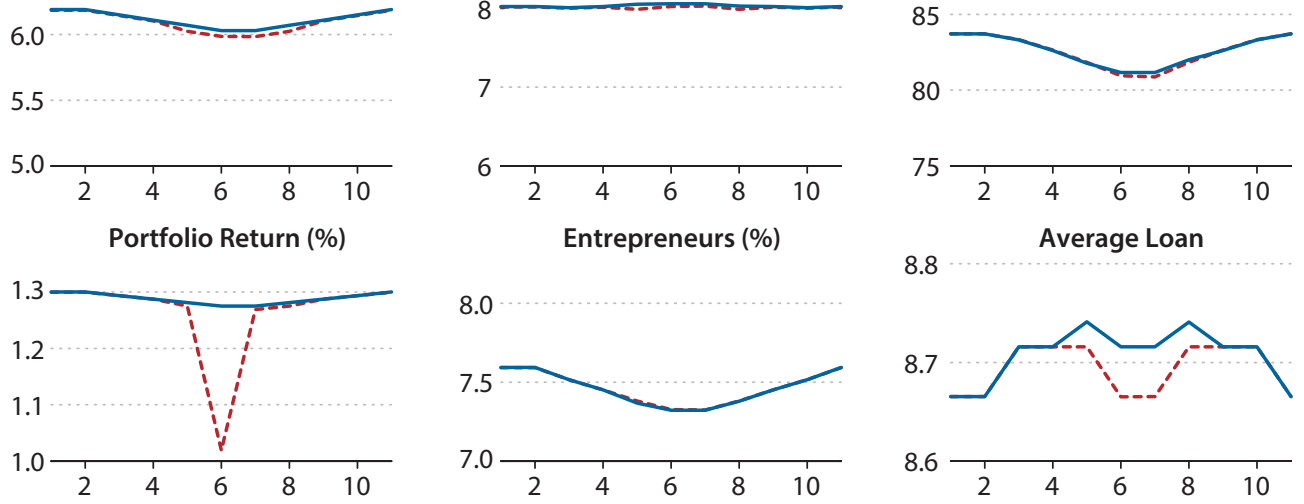

central bank reacts only after a prolonged decline in the economy. Note that the decisions of the banks are changed only in this specific state: $m^{*}$ and the lending rate are unaffected when the central bank does not move; but when it does move, banks reduce the lending rate by the same margin and, more importantly, significantly relax their loan threshold $m^{*}$. Thus, the situation for entrepreneurs should improve noticeably: easier access to credit at better conditions. Loan activity is negatively affected, however, and equity is reduced compared with the benchmark. This is because workers decide to save less (interest rates are lower) and put a smaller fraction of their savings into equity (its return drops more). Note that household decisions are affected even when the central bank has left the bond rate untouched, in anticipation of possible changes. Ultimately, the same number of entrepreneurs receives loans and the average loan is now smaller.

A one-time drop in the interest rate therefore does not appear to be an effective policy, as it weakly magnifies the credit cycle rather than smooths it. What if the interest rate is gradually 
Figure 3

\section{Benchmark and Policy with Gradual Interest Rate Reduction in Bad Return Situations}
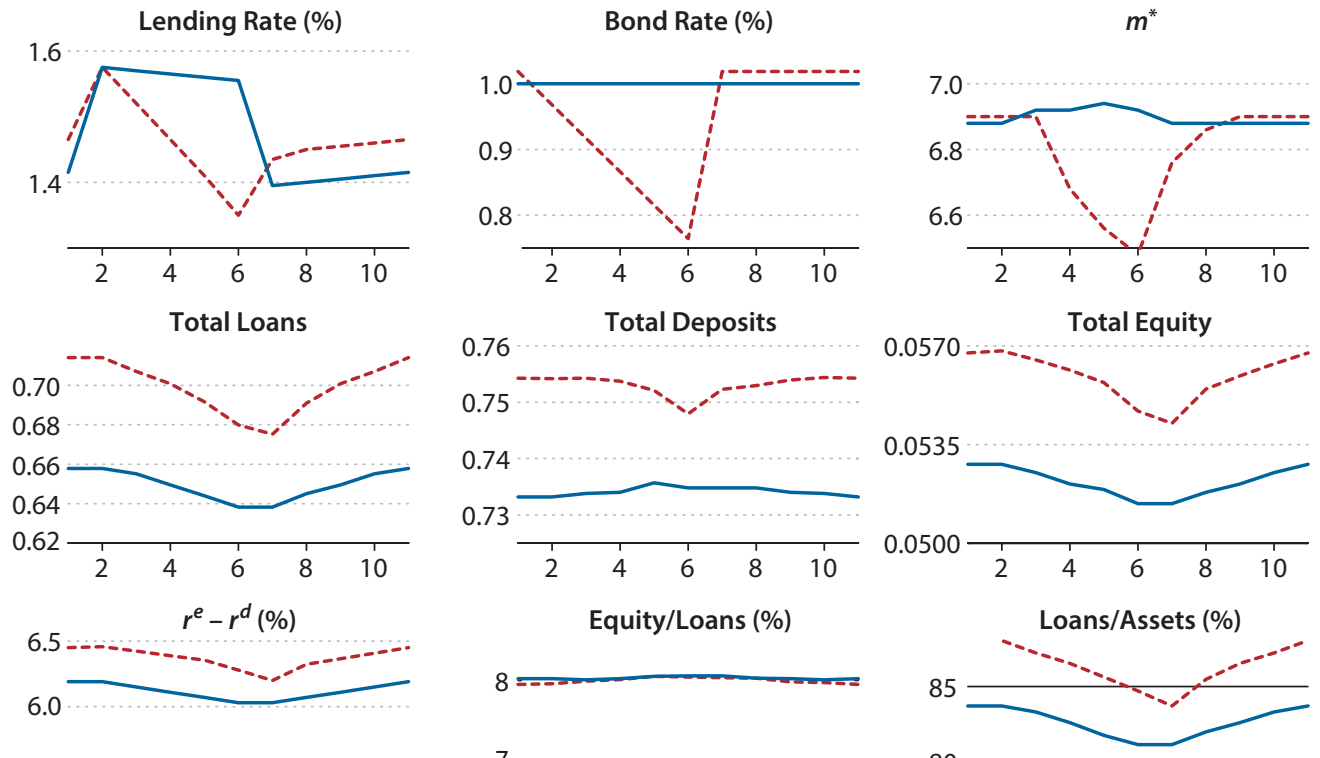

5.5

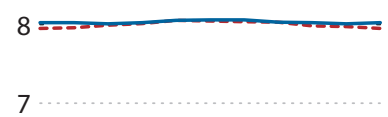

80
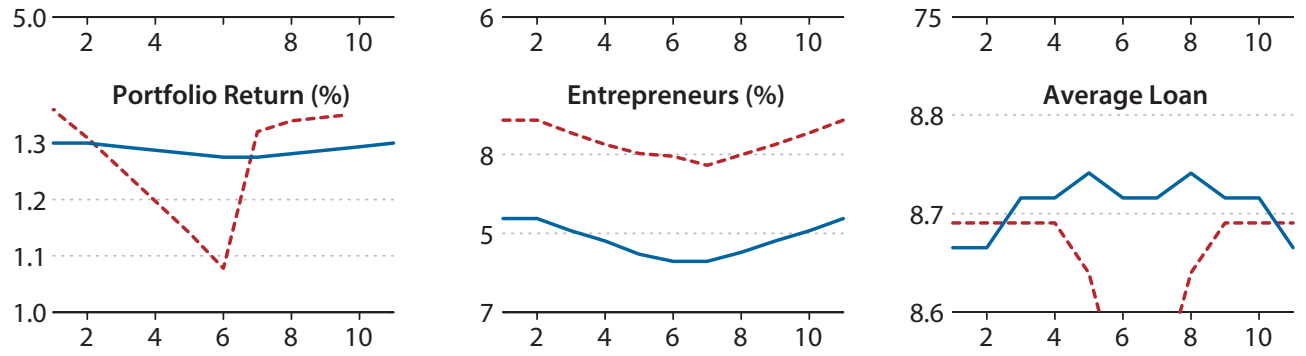

reduced by 5 points after each bad shock and goes back to normal whenever a good shock happens? This policy should better reflect the expectations that households formulate and consequently yield a stronger wealth effect. In Figure 3 we see that the outcome is quite different from Figure 2. Equity-rich banks are more generous to entrepreneurs in bad times, both in terms of lower lending rates in bad times (but higher in good ones) and, quite significantly, in terms of $m^{*}$. In all aggregate states, there are more entrepreneurs, loans, deposits, and equity. While the average loan is larger in normal times compared with the benchmark, it is smaller at almost any other time. This means that asset accumulation has increased for households: Entrepreneurship is more attractive as monetary policy counterbalances the increased risk in bad times. This effect is facilitated by an increasing spread that makes households' investment into bank equity more attractive. Indeed, while firms face lower average returns and higher bankruptcy rates, monetary policy forces banks to offer better conditions. This has an impact on asset accumulation even in good times because of households' long planning horizon. We 


\section{Figure 4}

\section{Benchmark and Policy with Interest Rate Increase in Worst Case Only}
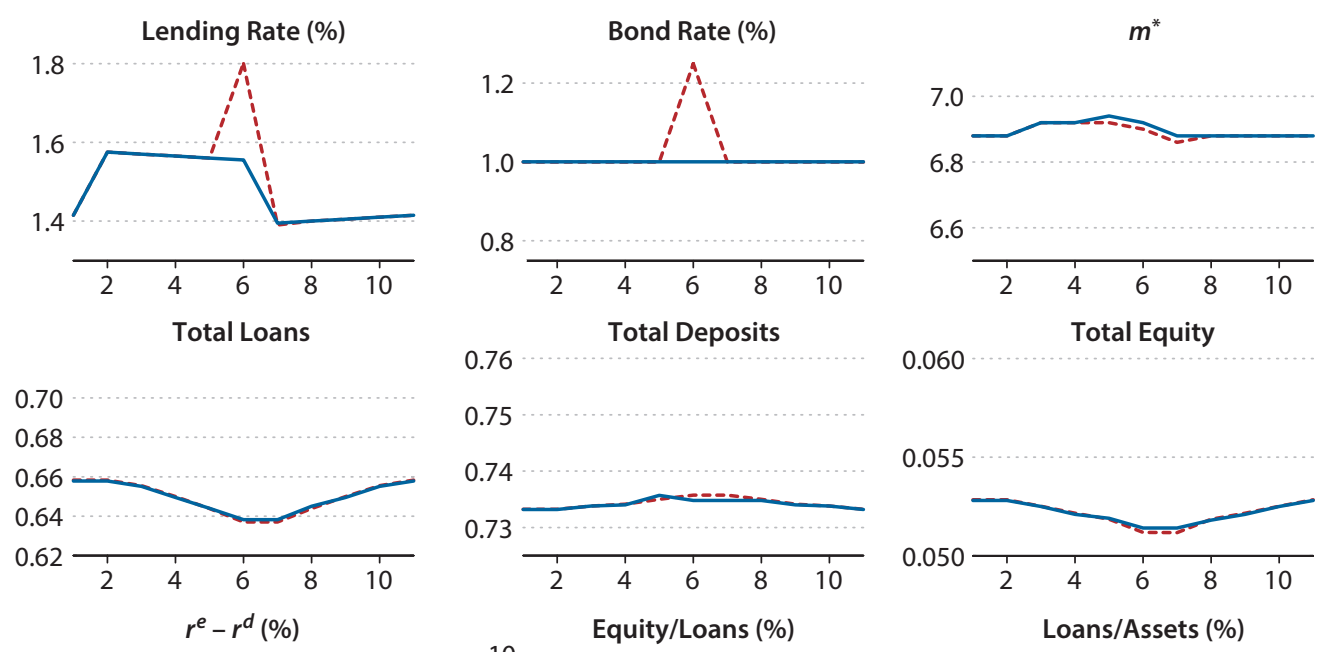

0.060
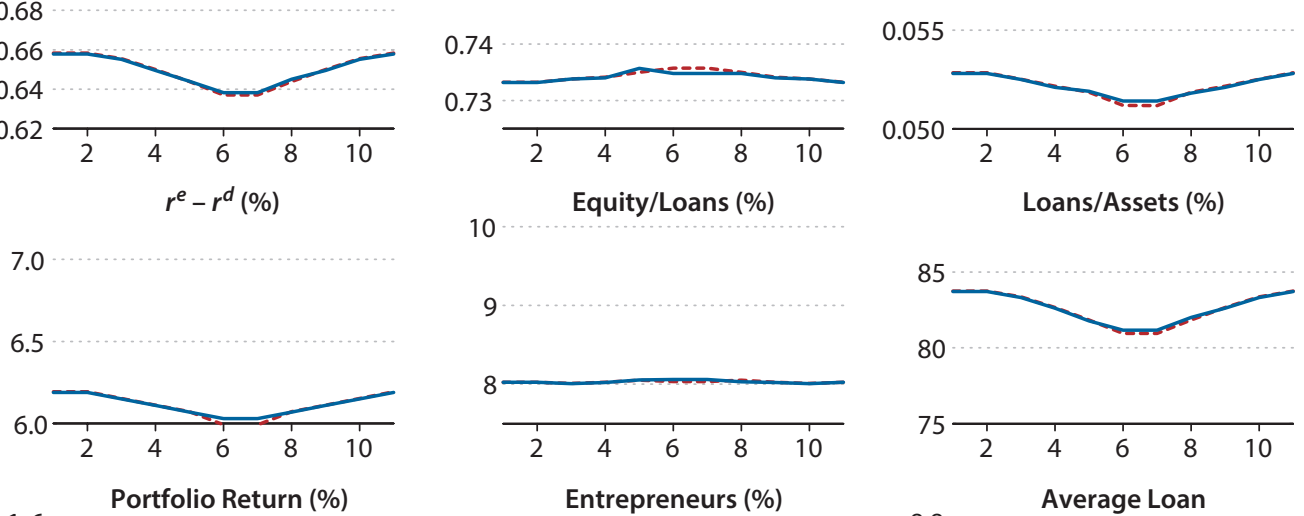

10

9
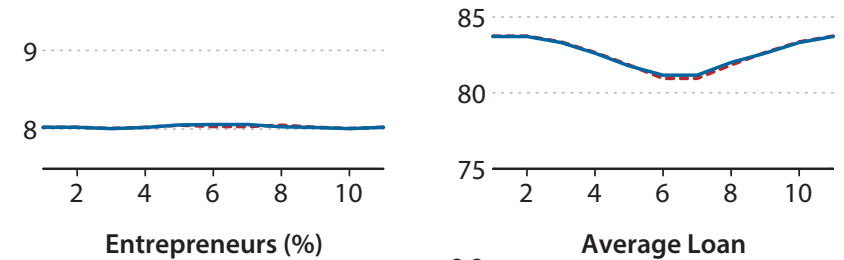

80

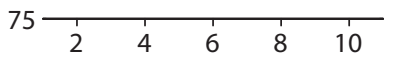

8.8
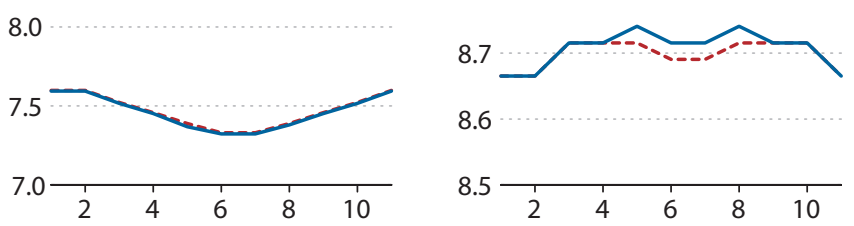

conclude that an active countercyclical monetary policy can have a significant positive impact. Note, however, that it cannot remove the cyclical nature of loans.

\subsection{Procyclical Monetary Policy}

If a policy of lower interest rates may have negative consequences under some circumstances, one may naturally ask whether higher interest rates can do some good. Indeed, higher bond rates mean higher returns on saving and potentially more equity to satisfy the loan needs in the presence of capital requirements.

In Figure 4 we find that the model economy does not behave in a symmetric way, as compared with Figure 2 . While the lending rate increases as expected, $m^{*}$ barely changes. Consequently, the loan activity does not change much as households barely change their decisions compared with the benchmark. The average loan size decreases. However, the change in the average loan size is smaller than in the countercyclical policy. 


\section{Figure 5}

\section{Benchmark and Policy with Gradual Interest Rate Increase as Aggregate States Worsen}
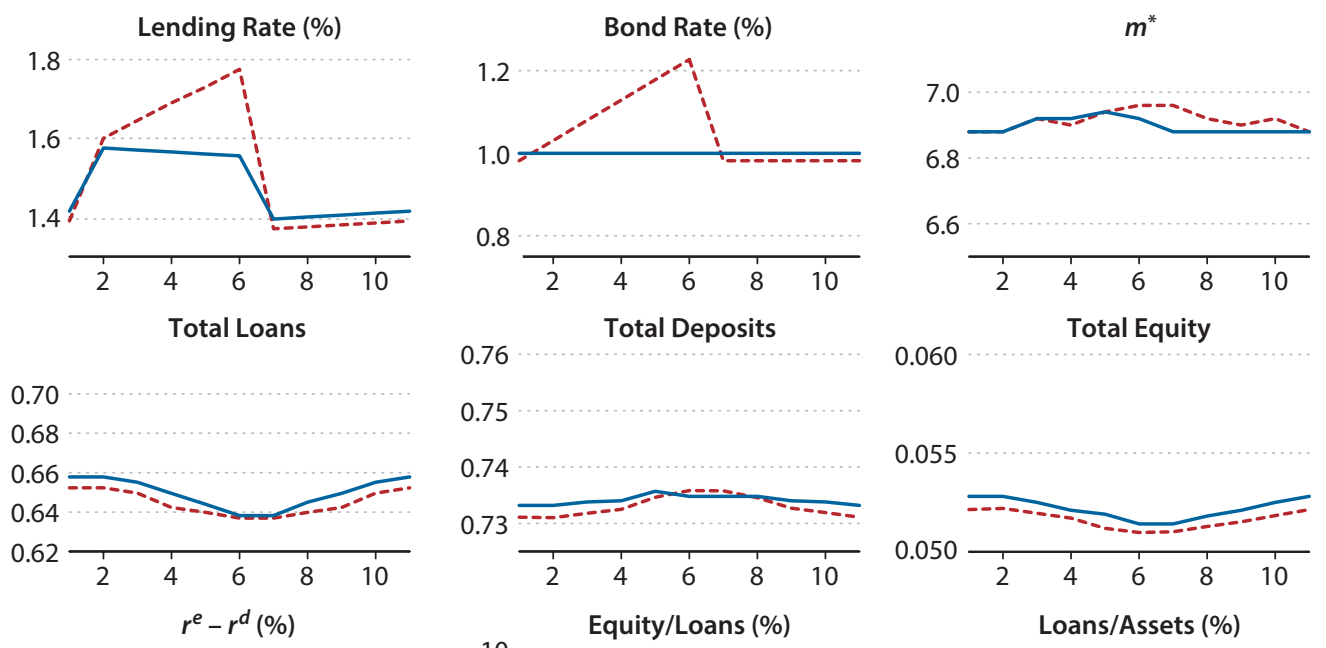

0.060

10

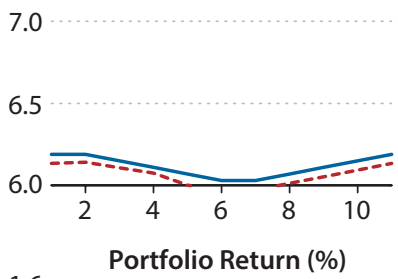

9
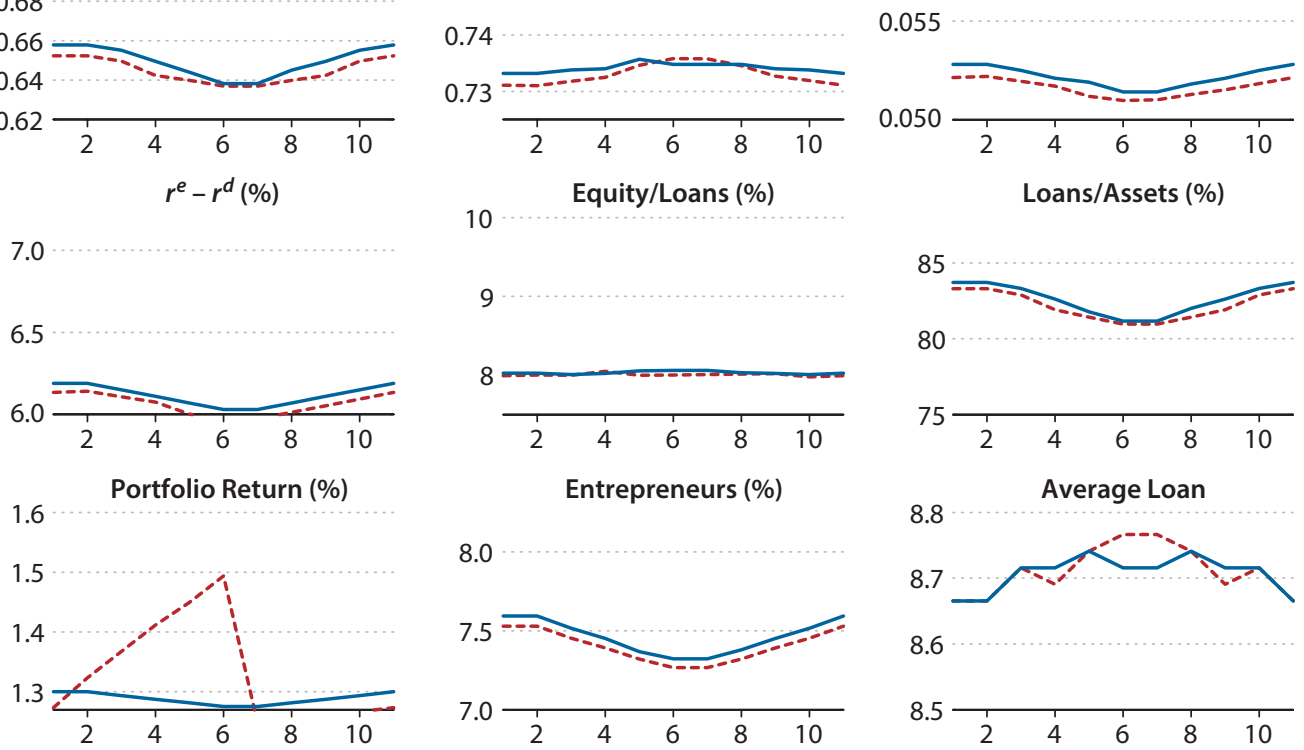

Figure 5 shows the model equilibrium when interest rates are increased gradually. The asymmetry of the monetary policy observed in Figure 3 is also present for the gradual policy. A gradual increase of the bond rate has a negative, but much smaller, impact on the various assets. The asymmetry of monetary policy due to the existence of credit constraints has been highlighted by Kocherlakota (2000). In our model, the explanation for this asymmetry is as follows. Countercyclical monetary policy induces a drop in $m^{*}$, leading to an increase in the loan volume as a greater number of smaller agents can become entrepreneurs. Moreover, a lower $m^{*}$ induces workers to save more (consumption drops) at any given deposit rate because entrepreneurship is more likely to be attained (a move that is slightly offset by the distributional movement from workers to entrepreneurs). Because of this boom in banks' liabilities, the asset side of banks' balance sheets expands, which reinforces the initial loan volume increase.

On the other hand, a gradual procyclical monetary policy induces a small rise in $m^{*}$. This is a strong saving disincentive for workers who want to become entrepreneurs, and it leads to 
Figure 6

Benchmark and Policy with Relaxing of Capital Requirements in Worst Case Only
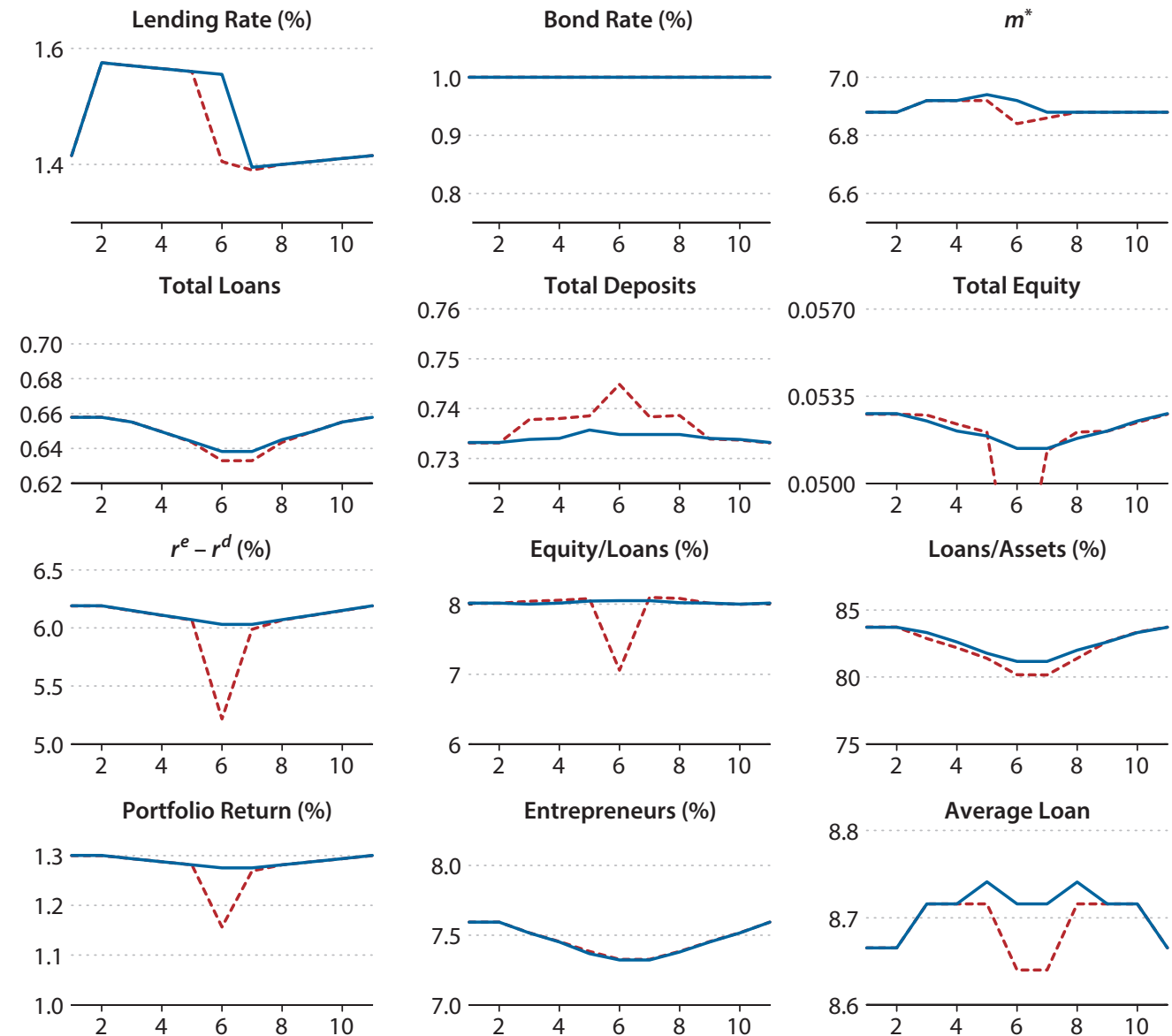

7
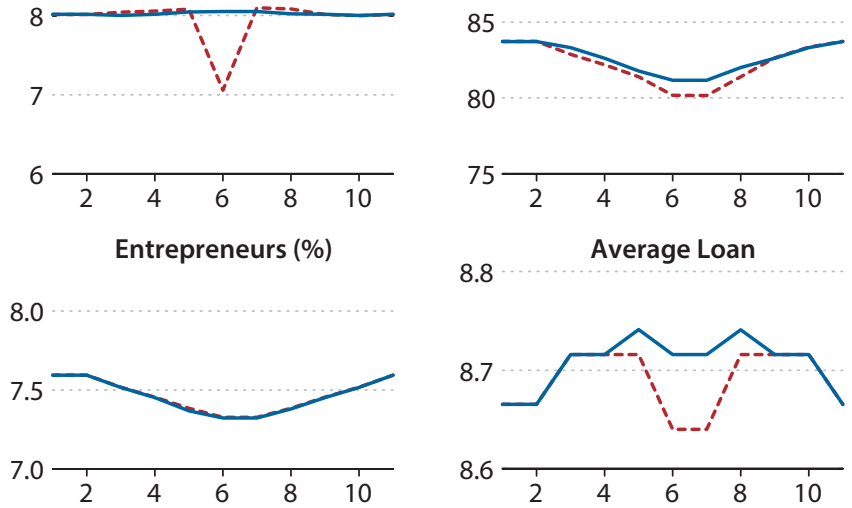

a drop in the volume of deposits and equity. Such a drop is offset by an increase of the pool of depositors and a rise in the deposit interest rate. Because of these offsetting effects, the net change in the volume and in the composition of banks' balance sheets is relatively small.

Such an offsetting distributional effect is stronger when $m^{*}$ rises because the distribution of agents is skewed in the neighborhood of $m^{*}$. Households have little reason to attain an asset level just below $m^{*}$ because of the higher expected utility of an entrepreneur than of a worker. Thus, an increase in $m^{*}$ has stronger consequences for loans than its decrease. This explains why $m^{*}$ does not have to rise as much as it has to decline.

Finally, banks' decision to change $m^{*}$ in an asymmetric way is just a reflection of the equilibrium nature of the problem. With a countercyclical monetary policy, in order for banks to give more loans, a rise in their equity funding is required (capital requirements bind). Yet the equity is more risky in bad states, and households channel their savings away from equity and into deposits. Therefore, to expand their loans, banks must make the vision of entrepre- 


\section{Figure 7}

\section{Benchmark and Policy with Gradual Relaxing of Capital Requirements as Aggregate States Worsen}
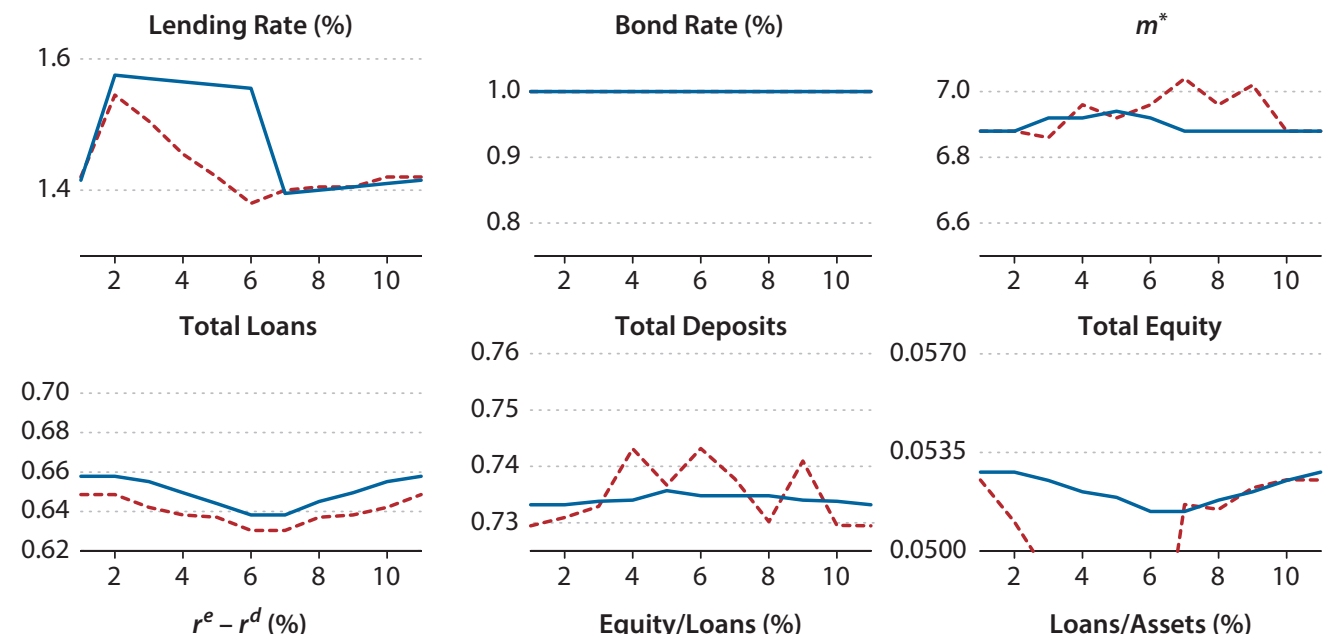

0.0570
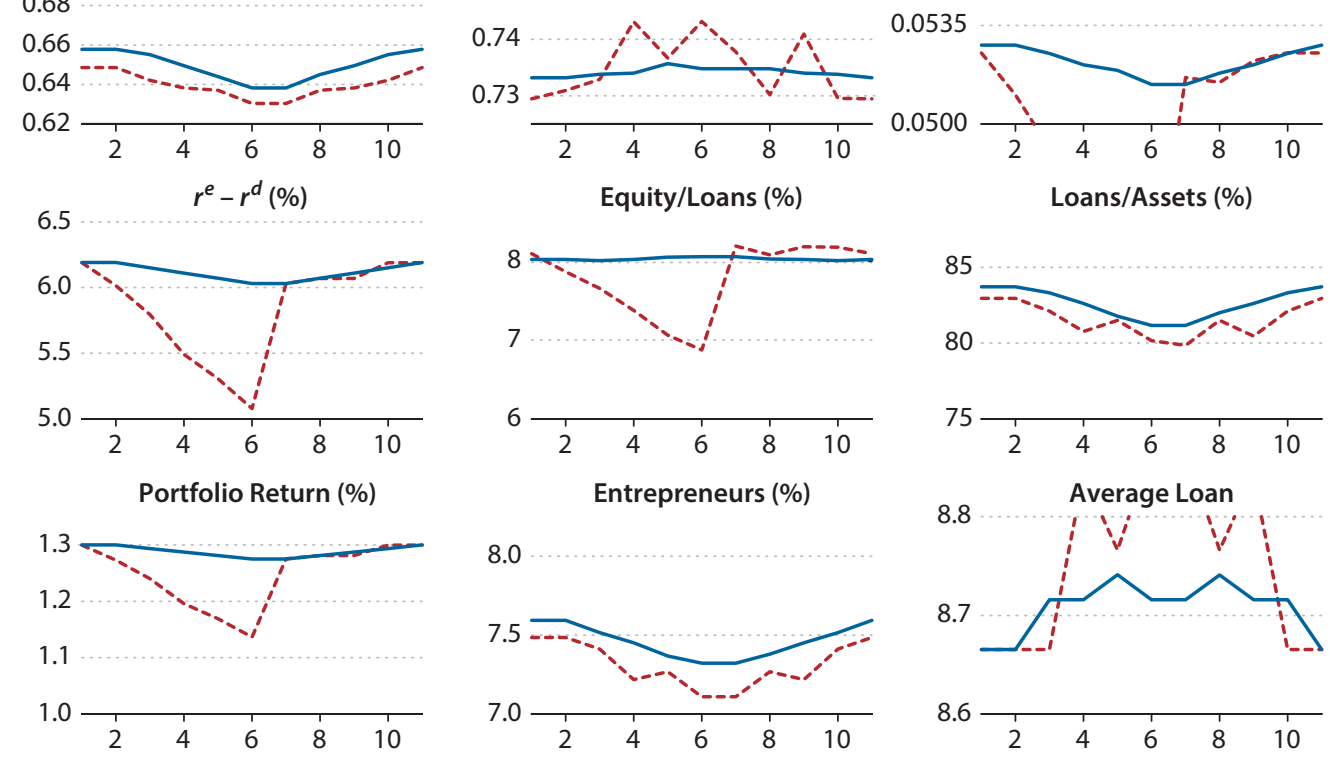

neurship - a motivation for saving-more desirable. This is why $m^{*}$ drops sharply. In contrast, a procyclical monetary policy achieves a loan volume drop by an increase in $m^{*}$. Such an increase can be small because for any amount of savings, risk-averse households prefer deposits in bad times anyway.

\subsection{Countercyclical Capital Requirements}

The interest rate is one of two instruments the central bank can use. The other is to modify the capital requirements, which in the benchmark economy are set at an 8 percent equity/loan ratio, as in the original Basel Accord. We now explore the policy of cyclical changes in capital requirements. In the first experiment (Figure 6), the equity/loan ratio is lowered to 7 percent in the worst aggregate state. This has two effects. First, it facilitates bank lending in the worst state. Second, households shift from equity to deposits because of the increased risk. The second effect is sufficiently large to counterbalance the first, resulting in a decrease of the loan 
Figure 8

Benchmark and Policy with Tightening of Capital Requirements in Worst Case Only
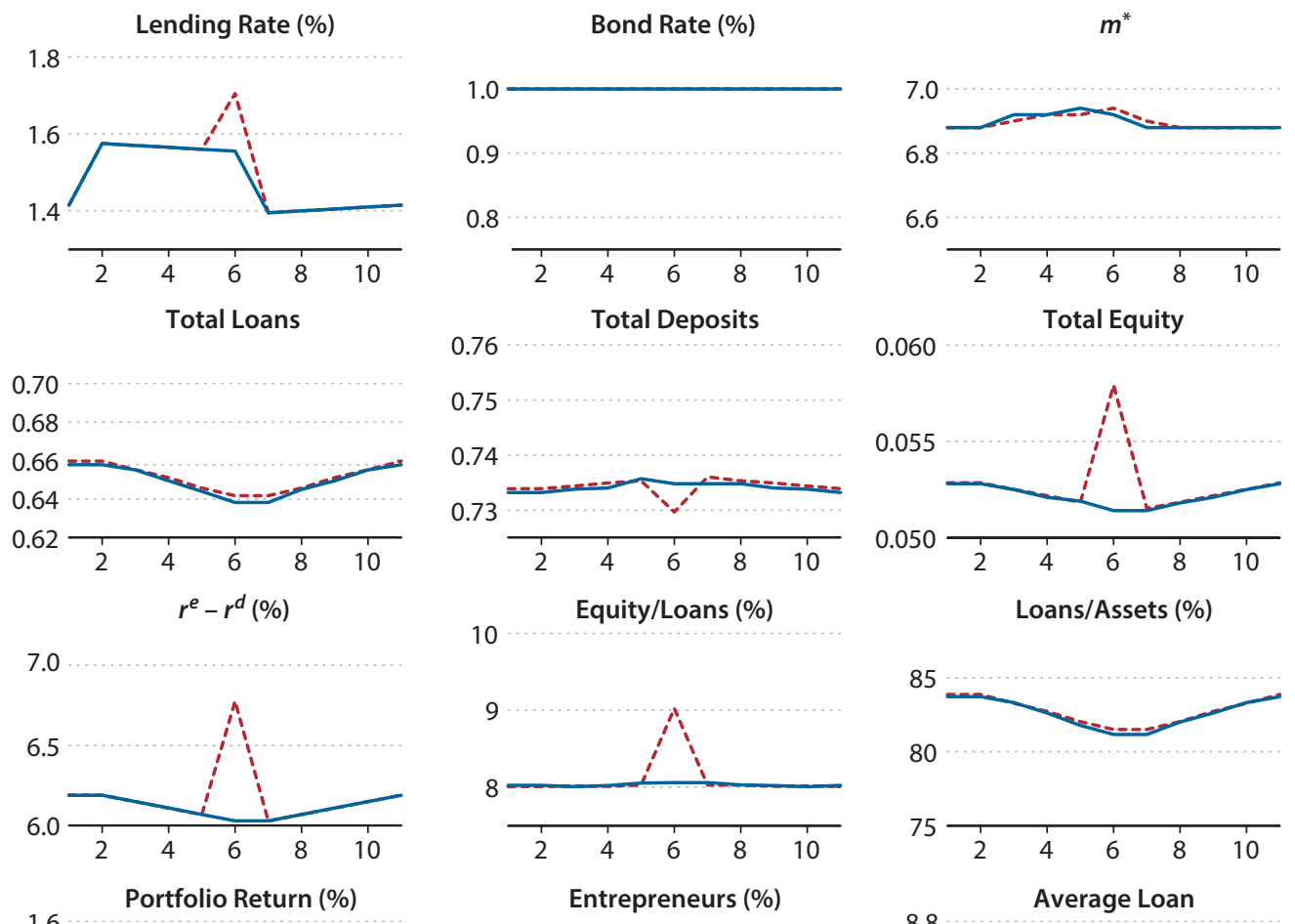

10
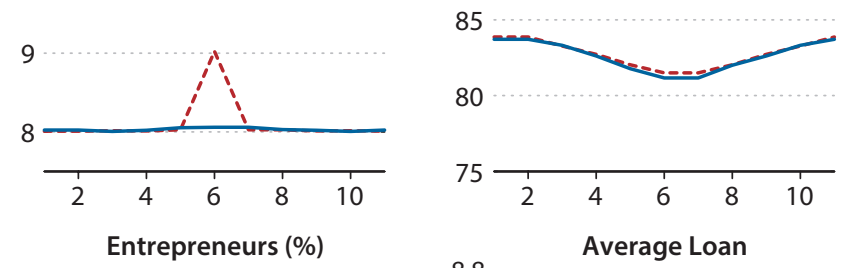

80
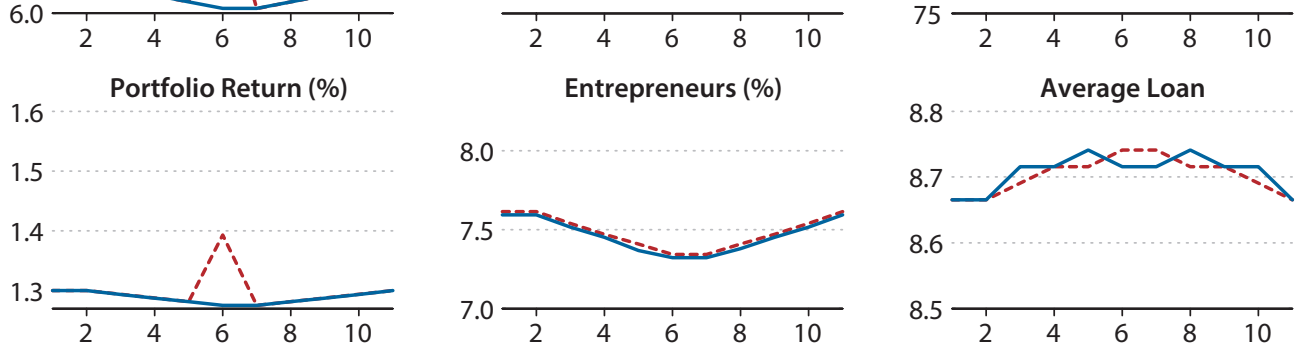

volume. As in the case of a bond rate reduction, the average loan size decreases as the number of entrepreneurs barely changes, compared with the benchmark economy.

The next experiment involves a gradual decline of the capital requirements during the bad shocks (Figure 7). One would expect that the regulator allowing the banks to take more risks during a downturn may generate more loans. To the contrary, equity declines even more, resulting in a smaller loan mass under a binding regulatory constraint. Interestingly, loans are lower even when the regulator does not intervene but has, in fact, slightly more stringent capital requirements to maintain the same average as in the benchmark. The reasons are the same as previously mentioned: Households shy away from banks when they take on more risk.

\subsection{Procyclical Capital Requirements}

If countercyclical capital requirements have adverse effects, maybe procyclical capital requirements have a positive impact on lending ability. Figure 8 looks at a one-time policy 


\section{Figure 9}

\section{Benchmark and Policy with Gradual Tightening of Capital Requirements as Aggregate States Worsen}
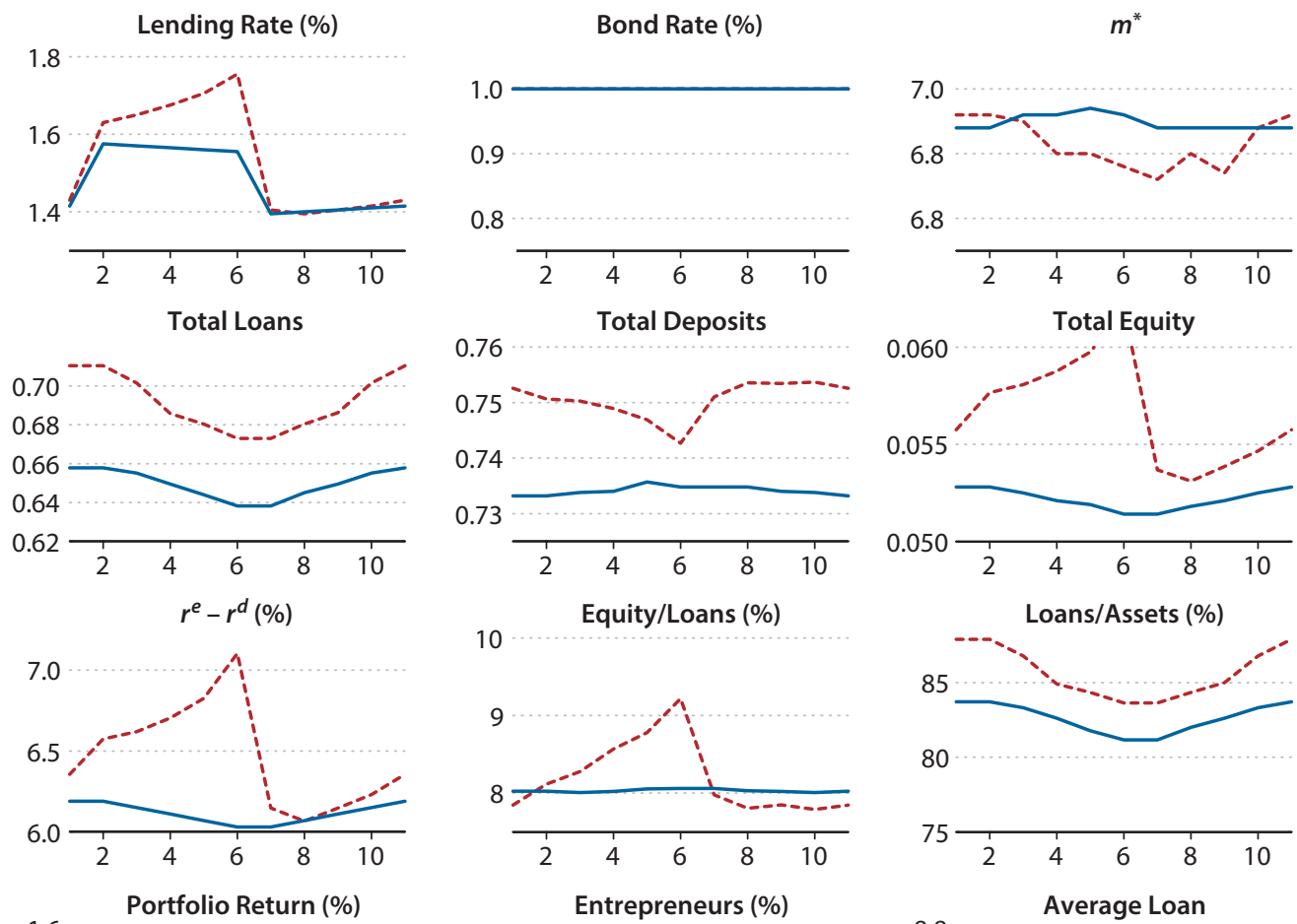

10
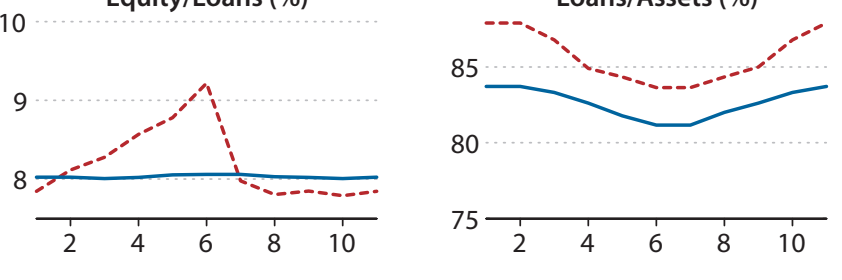

80
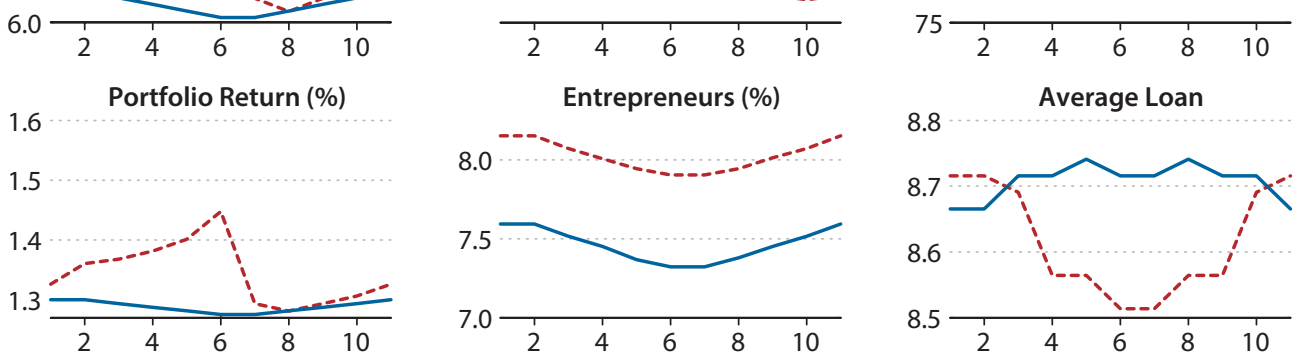

and Figure 9 at a gradual one. Both policies have positive effects, but the effects of a gradual policy are of a much larger magnitude. Tighter capital requirements increase loan activity by improving banks' financing. An increase in the equity-deposit spread facilitates the portfolio reallocation of households from deposits to equity, which relaxes banks' capital adequacy constraint. The lending rate increases in both the one-time and the gradual scenarios, to offset higher equity costs. In the gradual scenario, higher loan volume is facilitated by a drop in $m^{*}$. This brings in more entrepreneurs, both directly (those that were just below $m^{*}$ before its drop) and indirectly (increased saving), as entrepreneurship becomes more achievable to a wider spectrum of households (hence, the increase in deposits as well as equity). Smaller new loans cause a decline in the average loan size under this policy.

Although this policy effectively mimics the Basel Accord II stipulation of higher capital requirements in a downturn, its effects on the model economy contrast sharply with those described in the literature (Section 1). In the literature, the negative effect of tightening require- 
ments in a downturn is a result of a demand-side argument where higher capital-raising costs further contract banks' lending. However, such an argument ignores the effect of more stringent capital requirements on the supply of bank capital. In our model, this latter effect dominates and stringent capital requirements improve bank funding. Well-capitalized banks are both more attractive to savers and able to lend to previously ineligible borrowers (those initially just below $m^{*}$ ), which makes entrepreneurship more achievable.

Note that we have no informational problem in the model economy that would actually require the imposition of capital requirements. One can easily imagine that if the model would include this feature, it would only reinforce the result: The presence of more entrepreneurial risk leads to a higher impact of asymmetric information and risk, thus furthering the need for regulation.

\subsection{Credit Crunch? What Exactly Happens in the Model?}

A negative aggregate shock lowers the expected project returns and increases their volatility. This affects the loan volume and the lending rate in four ways. First, both effects decrease the expected value of risk-averse entrepreneurship $\left(E_{r} V_{E}\right)$, with no first-order effects on nonentrepreneurial households. $\frac{19}{}$ This lowers the incentive to accumulate assets to be eligible for a loan, thus lowering the demand for credit. Second, as the net payoff of bonds rises relative to the net payoff of loans, the risk-neutral bank switches from loans to bonds. This decreases the loan supply and increases the lending rate $r^{L}$ while also compensating for higher loan losses. This is the credit supply effect (i.e., the "crunch"). Third, an increase in $r^{L}$ further discourages loan applicants because their net return on investment declines-a movement along the demand curve for credit. Fourth, households shift from equity to insured deposits when the entrepreneurial (and hence bank equity) risk rises. This makes it harder for banks to meet the capital requirements, causing a further contraction of the loan volume. Thus, the decline in the market-clearing volume of credit is partly demand-driven, and it cannot be attributed solely to the credit crunch behavior of the banks. $\underline{20}$

\section{CONCLUSION}

We used a complex model to study the interaction of household saving decisions, project returns, Basel Accord-type banking regulations, and credit activity. We find that the Basel Accord has a noticeable impact on loans when project returns decline throughout the cycle. Active monetary policy through interest rate reductions in bad times can increase the loan volume without removing its cyclical nature.

A relaxation of the Basel Accord capital requirements in bad times obtains negative results, as households shy away from the equity that banks need to make loans. As in models with informational problems, which do not explicitly exist in our model, a tightening is in order. Therefore, this calls for regulatory policy to be active through the cycle, in the sense of Basel Accord II, which forces banks to adopt a risk evaluation method à la Merton, as pointed out by Catarineu-Rabell, Jackson, and Tsomocos (2005).

Our results also emphasize that it is important to take into account the financing of banks. Given capital requirements, banks are limited in their lending by the bank equity that 
households are willing to hold. As this decision is influenced by interest rates, it gives rise to another channel of monetary policy. This channel has also been identified by Chami and Cosimano (2010) and Van den Heuvel (2008). Unlike these papers, we do not require explicit asymmetric information, market power in the banking industry, or increasing marginal cost of financing.

\section{APPENDIX A: SOLVING THE BANKS' PROBLEM}

Because of the inequality constraints, we have to use a Kuhn-Tucker approach and be careful about the corner solutions. The Lagrangean for this problem is

$$
\begin{aligned}
& \mathcal{L}=r^{l} L+r^{b} B-r^{r} D-r^{e} E-\delta\left(\frac{D}{E}\right)^{\gamma} D-\left(1+l_{c}\right) \varepsilon L \\
& +\lambda_{1}(D+E-B-L)+\lambda_{2}(E / L-\alpha)+\lambda_{3}(D+E-L) .
\end{aligned}
$$

Then the first-order conditions are

$$
\begin{gathered}
r^{l}-\lambda_{1}-\lambda_{2} E / L^{2}-\lambda_{3}-\varepsilon\left(1+l_{c}\right)=0 \\
r^{b}-\lambda_{1}=0 \\
-r^{d}-\delta(\gamma-1)\left(\frac{D}{E}\right)^{\gamma}+\lambda_{1}+\lambda_{3}=0 \\
-r^{e}+\delta \gamma\left(\frac{D}{E}\right)^{\gamma+1}+\lambda_{1}+\lambda_{2} / L+\lambda_{3}=0 .
\end{gathered}
$$

As noted above, there are two possibilities: Either constraint (9) or constraint (10) binds. In terms of the Lagrangean, we therefore need to consider two cases. The one where $\lambda_{2}>0$ and $\lambda_{3}=0$ (i.e., [9] binds while [10] does not) will be referred to as an "interior solution" because not all loanable funds are invested into loans. The opposite case, where $\lambda_{3}>0$ and $\lambda_{2}=0$, will be referred to as a "corner solution." For simplicity, in what follows we assume $\gamma=1$.

\section{Interior Solution}

This is the case when banks hold just enough equity to satisfy the capital adequacy requirement $(E / L=\alpha$ and therefore $D+E>L)$. The above first-order conditions can be combined into

$$
\begin{gathered}
r^{d}=r^{b}-2 \delta \frac{D}{E} \\
\frac{M}{E}=1+\left[\frac{1}{\delta}\left(r^{e}-r^{d}\right)-\frac{1}{\alpha \delta}\left(r^{l}-r^{d}-\left(1+l_{c}\right) \varepsilon\right)\right]^{\frac{1}{2}} \\
L=\frac{1}{\alpha} E
\end{gathered}
$$




$$
D=\mathrm{M}-\mathrm{E},
$$

where (19) is an equity (or implicitly deposit) supply equation. Conditional on particular values of $M$ and all levels of prices, equations (18) to (21) form a recursive system that uniquely determines all quantities. Equations (19) and (6) imply

$$
\frac{1}{\delta}\left(r^{e}-r^{d}\right)^{3}-\left[\frac{1}{\alpha \delta}\left(r^{l}-r^{d}-\left(1+l_{c}\right) \varepsilon\right)+1\right]\left(r^{e}-r^{d}\right)^{2}+2 \lambda \sigma_{e}^{2}\left(r^{e}-r^{d}\right)-\lambda^{2} \sigma_{e}^{4}=0 .
$$

\section{Corner Solution}

In a corner solution, banks hold more equity than required by the capital adequacy requirement $(D+E=L$ and therefore $E / L>\alpha)$. Now $r^{b}>r^{d} \underline{21}$ and the above first-order conditions can be combined into

$$
\begin{gathered}
\frac{M}{E}=1+\left[\frac{r^{e}-r^{l}+\left(1+l_{c}\right) \varepsilon}{\delta}\right]^{\frac{1}{2}} \\
\mathrm{~L}=\mathrm{M} \\
\mathrm{D}=\mathrm{M}-\mathrm{E} \\
r^{l}-r^{b}-\left(1+l_{c}\right) \varepsilon=r^{b}-r^{d},
\end{gathered}
$$

where (23) is again an equity supply equation. Note that now loan and equity supply decisions are disconnected. Equation (26) shows a wedge between the bond and deposit rates. The bond "premium" on the right-hand side equals the profit differential between net returns on loans and bonds that would equal zero in an interior solution. Equations (23) and (6) imply

$$
\begin{array}{r}
r^{e 3}-r^{e 2}\left[2 r^{d}+r^{l}-\left(1+l_{c}\right) \varepsilon+1\right]-r^{e}\left[r^{d^{2}}+2 r^{d}\left(r^{l}-\left(1+l_{c}\right) \varepsilon+1\right)+2 \lambda \sigma_{e}^{2}\right] \\
-\left[r^{d^{2}}\left(r^{l}-\left(1+l_{c}\right) \varepsilon+1\right)+2 \lambda \sigma_{e}^{2} r^{d}+\delta \lambda^{2} \sigma_{e}^{4}\right]=0 .
\end{array}
$$

Market clearing condition (22) defines a return on equity as $r^{e}=r^{e}\left(r^{l}, r^{d}, \sigma_{e}^{2}, \lambda, \alpha\right)$. The cubic equation can be solved analytically but does not determine the $r^{e}$ uniquely. Depending on the parameter values, two of the three roots may be complex. We disregard complex roots.

The system is then recursive: Conditional on $M$, equation (19) determines the optimal level of equity $E$, equation (21) determines the optimal level of deposits $D$, equation (14) determines the optimal level of bonds $B$, and equation (20) determines the optimal level of loans $L$. We therefore have $\left\{r^{e}, r^{d}, E, D, L, B\right\}$ as a function of $\left\{r^{l}, M\right\}$ and exogenous variables. 


\section{APPENDIX B: PORTFOLIO OPTIMIZATION}

The Euler equation for equity is

$$
\begin{aligned}
& M U_{t}=\beta E_{t}\left[M U_{t+1} R_{t+1}^{e}\right] \\
& M U_{t}=\beta E_{t}\left[M U_{t+1}\right] E_{t}\left[R_{t+1}^{e}\right]+\operatorname{cov}_{t}\left(M U_{t+1}, R_{t+1}^{e}\right) .
\end{aligned}
$$

Because returns on equity are uncertain, the covariance between expected gross return and expected marginal utility at $t+1$ affects consumption decisions of households in equilibrium. The intuition is easy to see if we think of starting from certain returns on equity and then allow for uncertainty with cov $>0$ : Returns on equity tend to be high when $M U$ of consumption is high. Such change makes allocations under certainty suboptimal because $M U_{t}<P V\left(E_{t} M U_{t+1}\right)$. An intertemporal reallocation, by shifting consumption from today to the future period, increases $M U_{t}$ and lowers $M U_{t+1}$, which brings the Euler equation into balance. So when comovement between $M U$ and $R^{e}$ is positive-an empirical regularity, see Duffee (2005) - households save more through equity than through deposits with the same return ( $R^{d}$ is certain). A non-zero covariance justifies existence of two assets in equilibrium.

This implies differences in saving patterns across heterogeneous agents arising from differences in their expected income (and consumption) levels. On average, entrepreneurs earn most, workers less, and the retired and unemployed least of all. With increasing and concave utility, $M U^{\text {worker }}<M U^{\text {retired }}<M U^{\text {unemployed }}$. 22 If $\operatorname{cov}\left(M U, R^{e}\right)$ is a constant wedge, the last Euler equation above implies that covariance between $R^{e}$ and $C$ will be least important for agents with highest average $M U$ (unemployed) and most important for workers because of their low $M U$. Then, workers will save most via equity while the unemployed will save least via equity because the comovement of risky returns is relatively less important when $M U$ is high.

To implement this idea in the scope of our model, we introduce three mutual funds for each of the three types of depositors: workers, the unemployed, and the retired. Equation (6) shows that the decisions of workers, the unemployed, and the retired when choosing a share of risky equity in their saving portfolio depend on their risk aversion parameter $\lambda_{i}$. Guided by the above discussion and standard micro theory, we calibrate $\lambda_{i}$ as proportional to the distance $X_{i}$ between utility of mean consumption $U\left(\bar{C}_{i}\right)$ and average of utilities $U\left(\bar{C}_{i}-T\right)$ and $U\left(\bar{C}_{i}+T\right)$, where $T$ is chosen to clear the equity market $\left(E_{W}+E_{U}+E_{R}=E\right)$. Specifically for workers (and similarly for the unemployed and retired), $\lambda_{W}=\frac{M_{W}+M_{U} \frac{X_{W}}{X_{U}}+M_{R} \frac{X_{U}}{X_{R}}}{M / \lambda}$, where $\lambda$ is the aggregate lambda implied by the overall market's equity holdings (the homogeneous part of the model), and $M_{i}$ is the overall asset holding of agent type $i$. 


\section{APPENDIX C: THE SOLUTION PROCEDURE}

Heterogeneous agent models with aggregate shocks are difficult to solve because the distribution of agents is not invariant and becomes a highly dimensional state variable. The two main strategies to solve this problem are either to find a good way to summarize the distribution with very few variables, as Krusell and Smith (1998) demonstrate, or to work with linearization, as Cooley and Quadrini (2006) do. Unfortunately, neither is possible here because of some highly nonlinear phenomena that are crucial in our model. For example, decision rules change abruptly in the vicinity of $m^{*}$. Finally, second-degree effects appear to be quite important, and they are likely to vanish with linearization.

Our strategy uses the realization that aggregate shocks in a two-state Markov process lead to transitional states somewhere between two steady states that correspond to repeated identical shocks. We therefore choose a sufficient number of aggregate states to represent a large proportion of actual aggregate states.

The aggregate state space is assumed two-dimensional: One dimension is the current shock, high or low, and the other is a counter of how far from the high steady state the economy is. Specifically, this counter increased by one each time a low shock occurred in the previous period, or it decreased by one if a high shock occurred. The minimum counter value is one; the maximum value is chosen as an infrequently occurring state. We choose a maximum of five, implying with the transition probabilities of the Markov process that the economy will in any of the aggregate states $S_{s c}$ percent of the time, where

$$
S=\left(\begin{array}{rrrrr}
50.2 & 16.7 & 5.6 & 1.9 & 0.6 \\
16.7 & 5.6 & 1.9 & 0.6 & 0.2
\end{array}\right)
$$

We then solve this model economy with the standard tools for heterogeneous agent economies - that is, value function iterations followed by iterations on the invariant distribution (defined over the aggregate states as well). The equilibrium is reached by finding the set of lending rates $r^{l}$ and loan eligibility rules $m^{*}$ that balance all markets and satisfy all constraints in all aggregate states. 


\section{APPENDIX D: DOES THE EQUITY MARKET WORSEN OR SOFTEN THE CREDIT DECLINE?}

The existence of the equity market can either amplify or reduce the impact of a negative shock on a volume of credit. Only the second and fourth of the four effects mentioned in Section 4.5 depend directly on the equity market. The equilibrium condition (22) shows that only changes in $r^{L}$ and $\varepsilon$ affect credit behavior through the equity channel, and they do so in an offsetting manner. An increase in $\varepsilon$ (higher loan losses) increases the return on equity $r^{E}$, while an increase in $r^{L}$ lowers it. We therefore distinguish two cases. Case (A): If $\mathrm{d}\left(r^{L}-\left(1+l_{c}\right) \varepsilon\right)<0$, then a rise in $r^{E}$ increases the cost of funds to the bank, which squeezes the profit margin further and leads to an additional substitution of bonds for loans ( $L^{S}$ drops), as well as an increase in $r^{L}$. At the same time, the portfolio return $r^{\text {port }}$ increases, making borrowing relatively less attractive (demand for credit drops). In this case, the presence of the equity market worsens the credit decline: A higher $r^{E}$ is only compatible with a lower amount of equity $E$ on the market, as households are risk averse while banks are risk neutral, which in turn requires an additional drop in loans because of a binding capital adequacy constraint (equation [20]). Case (B): When $\mathrm{d}\left(r^{L}-\left(1+l_{c}\right) \varepsilon\right)>0$ has the opposite implication, it softens the effects of a financial accelerator. According to the simulations (comparing peak and trough states), $\mathrm{d}\left(r^{L}-\left(1+l_{c}\right) \varepsilon\right)=0.0002$, and we can conclude that the presence of the equity market softens the credit crunch. 


\section{Berka and Zimmermann}

\section{NOTES}

1 The empirical relevance of the standard bank-lending channel has recently been questioned by den Haan, Sumner, and Yamashiro (2007), who document large loan portfolio changes following monetary contractions.

2 The heterogeneity of firms we obtain is endogenous. Bernanke, Gertler, and Gilchrist (1999) also have heterogeneous firms, but they exogenously fix a share of firms to have easy access to credit.

3 Regulations in many countries limit or prevent banks from investing equity (capital) in their borrowers' businesses, arguably to limit their risk exposure. However, the contribution of the model in Meh and Moran (2004) is based on the assumption that implies that banks invest a share of their capital into borrowers' businesses.

4 Empirically, such earnings shocks are critical for the saving decisions, as outlined in the 2001 Survey of Consumer Finances (Chatterjee et al., 2007).

$\underline{5}$ Once retired, a household cannot become productive again. This innocuous assumption simplifies the calibration of birth rates.

6 Kocherlakota (2000) shows how credit constraints are fundamental for the amplification of income shocks at a macroeconomic level when capital and labor shares in the production function are substantial. Our net worth constraint works in a similar manner, but by rationing an endogenous mass of the agent distribution with positive assets below some $m^{*}$. The assumption that the project size $x$ is proportional to the entrepreneur's assets $m$ is a simplification: It allows the proportionality parameter $\phi$ to be easily calibrated from aggregate data, and it retains the essential mechanism needed for the functioning of the model: collateral needs and a mechanism to measure the tightening of credit conditions.

7 Consumption insurance is used in a number of papers, recently in Gertler and Karadi (2011). Note that in our model, banks provide $c_{\min }$. This follows typical bankruptcy law, where creditors are limited in the assets they can claim so that the bankrupted can enjoy a minimum standard of living.

$\underline{8}$ Another way is to think of labor income in our model as a numeraire.

9 We will justify in the calibration the use of $\xi$.

10 A prime (') denotes variable values in the next period.

11 All equilibria in such bimodal distribution are very unstable because all entrepreneurs can drift to zero assets following a shock. The distribution of assets plays a crucial role in determining the dynamics of the aggregate variables.

12 In the real world, this could be compared with retirees choosing the "safe" mutual fund investment option, employees choosing a "balanced" option, and entrepreneurs choosing a "growth" option. This is consistent with the evidence that risk aversion declines with wealth, and it is what we are trying to capture in a reduced form.

$\underline{13}$ One can think of banks depositing their non-loanable investments at the central bank, which also sets the deposit rate in this model.

14 This follows from the fact that $\frac{E}{D}=\frac{\omega_{r}}{1-\omega_{r}}$ and $\omega_{r}$ increases in $r^{e}$.

15 Two cases can occur. First, if new loans do not exhaust the new balance sheet level, loan market clearing conditions are satisfied and constitute a potential equilibrium. Second, if new loan volume exceeds the new balance sheet volume $M$, we have a corner solution. Then, the loan market does not clear and the banks ration some of the eligible loan applicants. Since an increase in the price of loans does not affect their quality in our model, a higher $r^{\prime}$ is needed to clear the market. Therefore, we have a choice of focusing on market-clearing equilibria that rule out corner solutions and equity "hoarding" or of allowing credit rationing when multiple equilibria may arise and when excess equity is kept as a backup in case the total amount of loanable funds $M$ increases. For simplicity, we focus on the market-clearing equilibria, implying that equation (27) becomes irrelevant. Therefore, banks do not hold excess equity in equilibrium, and regulatory changes in capital adequacy ratio $\rho$ have a direct effect on the loan volume.

16 This measure is based on the effective replacement rate of Hornstein and Yuan (1999).

17 The recent literature described above discusses how procyclical bank capital requirements arise in the scope of Basel II. Yet in our model, banks effectively operate under Basel I.

18 Note that all experiments are designed such that the average $r^{b}$ or $m^{*}$ stays at the same level. 
19 There is a second-order effect coming from expectations to be an entrepreneur in the future.

20 See Appendix D for more discussion.

$\underline{21}$ A lower demand for banks' financing by deposits (relative to equity) depresses their price.

$\underline{22}$ Retirees have more free time than workers and the unemployed.

\section{REFERENCES}

Baum, Christopher; Caglayan, Mustafa and Ozkan, Neslihan. "The Impact of Macroeconomic Uncertainty on Bank Lending Behavior." Working paper, Boston College, 2002; https://ideas.repec.org/p/sce/scecf2/94.html.

Bernanke, Ben and Gertler, Mark. "Agency Costs, Net Worth and Business Fluctuations." American Economic Review, March 1989, 79(1), pp. 14-31; http://www.econ.nyu.edu/user/gertlerm/BernankeGertlerAER.pdf.

Bernanke, Ben and Gertler, Mark. "Inside the Black Box, the Credit Channel of Monetary Policy Transmission." Journal of Economic Perspectives, Fall 1995, 9(4), pp. 27-48; https://doi.org/10.1257/jep.9.4.27.

Bernanke, Ben; Gertler, Mark and Gilchrist, Simon. "Chapter 21 - The Financial Accelerator in a Quantitative Business Cycle Framework." Handbook of Macroeconomics, Elsevier, 1999, 1(part C), pp. 1341-1393; https://doi.org/10.1016/S1574-0048(99)10034-X.

Bolton, Patrick and Freixas, Xavier. "Corporate Finance and the Monetary Transmission Mechanism." Review of Financial Studies, 2006, 19(3), pp. 829-870; https://doi.org/10.1093/rfs/hhl002.

Catarineu-Rabell, Eva; Jackson, Patricia and Tsomocos, Dimitrios. "Procyclicality and the New Basel Accord-Banks' Choice of Loan Rating System." Economic Theory, October 2005, 26(3), pp. 537-557; https://doi.org/10.1007/s00199-004-0534-0.

Chami, Ralph and Cosimano, Thomas. "Monetary Policy with a Touch of Basel." Journal of Economics and Business, May-June 2010, 62(3), pp.161-175; https://doi.org/10.1016/j.jeconbus.2009.12.001.

Chatterjee, Satyajit; Corbae, Dean; Nakajima, Makoto and Ríos-Rull, José-Víctor. "A Quantitative Theory of Unsecured Consumer Credit with Risk of Default." Econometrica, November 2007, 75(6), pp. 1525-1589; https://doi.org/10.1111/j.1468-0262.2007.00806.x.

Cooley, Thomas and Quadrini, Vincenzo. "Monetary Policy and the Financial Decisions of Firms." Economic Theory, January 2006, 27(1), pp. 243-270; https://doi.org/10.1007/s00199-004-0553-x.

Covas, Francisco and Fujita, Shigeru. "Procyclicality of Capital Requirements in a General Equilibrium Model of Liquidity Dependence." International Journal of Central Banking, December 2010, pp. 137-173; http://www.ijcb.org/journal/ijcb10q4a7.htm.

den Haan, Wouter J.; Sumner, Steven and Yamashiro, Guy. "Bank Loan Portfolios and the Monetary Transmission Mechanism." Journal of Monetary Economics, April 2007, 54(3), pp. 904-925; https://doi.org/10.1016/j.jmoneco.2006.01.008.

Duffee, Gregory. "Time Variation in the Covariance Between Stock Returns and Consumption Growth." Journal of Finance, August 2005, 60(4), pp. 1673-1712; https://doi.org/10.1111/j.1540-6261.2005.00777.x.

Gertler, Mark and Karadi, Peter. "A Model of Unconventional Monetary Policy." Journal of Monetary Economics, January 2011, 58(1), pp. 17-34; https://doi.org/10.1016/j.jmoneco.2010.10.004.

Heid, Frank. "The Cyclical Effects of the Basel II Capital Requirements." Journal of Banking \& Finance, December 2007, 31(12), pp. 3885-3900; https://doi.org/10.1016/j.jbankfin.2007.03.004.

Hornstein, Andreas and Yuan, Mingwei. "Can a Matching Model Explain the Long-Run Increase in Canada's Unemployment Rate?" Canadian Journal of Economics, August 1999, 32(4), pp. 878-905; https://doi.org/10.2307/136409.

Kashyap, Anil and Stein, Jeremy. "Cyclical Implications of the Basel II Capital Standards." Economic Perspectives, 2004, 28(1), pp. 18-31; https://ideas.repec.org/a/fip/fedhep/y2004iqip18-31nv.28no.1.html. 


\section{Berka and Zimmermann}

Kato, Ryo. "Liquidity, Infinite Horizons and Macroeconomic Fluctuations." European Economic Review, July 2006, 50(5) pp. 1105-1130; https://doi.org/10.1016/j.euroecorev.2005.01.010.

Kocherlakota, Narayana. "Creating Business Cycles Through Credit Constraints." Federal Reserve Bank of Minneapolis Quarterly Review, Summer 2000, 24(3), pp. 2-10; https://minneapolisfed.org/research/qr/qr2431.pdf.

Krusell, Per and Smith, Jr., Anthony. "Income and Wealth Heterogeneity in the Macroeconomy." Journal of Political Economy, October 1998, 106(5), pp. 867-896; https://doi.org/10.1086/250034.

Meh, Césaire and Moran, Kevin. "Bank Capital, Agency Costs, and Monetary Policy." Working Paper 2004-6, Bank of Canada, 2004; http://www.bankofcanada.ca/wp-content/uploads/2010/02/wp04-6.pdf.

Repullo, Rafael and Suarez, Javier. "The Procyclical Effects of Bank Capital Regulation." Review of Financial Studies, February 2013, 26(2), pp. 452-490; https://doi.org/10.1093/rfs/hhs118.

Statistics Canada. "Quarterly Financial Statistics for Enterprises." Technical Report, Third Quarter 1994. Catalogue no. 61-008XPB. http://www5.statcan.gc.ca/olc-cel/olc.action?Objld=61-008-X\&ObjType=2\&lang=en\&Limit=1 (publication discontinued).

Van den Heuvel, Skander. "Does Bank Capital Matter for Monetary Transmission?" Economic Policy Review, May 2002, 8(1), pp. 259-265; https://doi.org/10.1016/j.jmoneco.2007.12.001.

Van den Heuvel, Skander. "The Welfare Costs of Bank Capital Requirements." Journal of Monetary Economics, March 2008, 55, pp. 259-266; https://ideas.repec.org/a/eee/moneco/v55y2008i2p298-320.html.

Williamson, Stephen D. "Financial Intermediation, Business Failures, and Real Business Cycles." Journal of Political Economy, December 1987, 95(6), pp. 1196-1216; https://doi.org/10.1086/261511.

Yuan, Mingwei and Zimmermann, Christian. "Credit Crunch in a Model of Financial Intermediation and Occupational Choice." Journal of Macroeconomics, December 2004, 26(4) pp. 637-659;

https://doi.org/10.1016/j.jmacro.2003.05.002. 